\title{
O segredo do boi misterioso nos romances de vaqueiros ${ }^{1}$
}

\author{
GIULlE VIEIRA DA MATA \\ Sete Lagoas. Brasil
}

Aquele que imola um boi, mata um bomem.

(Isaías 66, 3)

\section{RESUMEN}

La autora propone un análisis socio-fenomenológico de los romances del Ciclo do Gado brasileños. Descodificando el lenguaje simbólico de los textos, procura identificar la brecha en la estructura de la comunidad de vaqueros (que permite a un solo individuo constituirse en "centro" de este sistema social), así como los procesos por los cuales este mismo individuo es reincorporado al grupo. Al mismo tiempo que el individuo es incentivado a desprenderse de ciertas dependencias grupales, las gestas aquí analizadas dan testimonio de su deseo de participación en el modo de ser del grupo y de su fidelidad al carácter tradicional de la comunidad de que forma parte.

Palabras clave: Poesía popular, Buey, Vaquero, Construcción identitaria, Brasil.

\section{SUMMARY}

The author proposes a socio-phenomenological analysis of the ballads of the Brazilian Ciclo do Gado. By decoding the symbolic language of the texts, she seeks to identify the breach in the structure of the herdsmen's community that allows an individual to be the "center" of the social system and the processes by which the community reassimilates him. At the same time that the individual has a motivation to break up whith some grupal interdependencies, the gestas here analyzed express his desire of participation in the group and his loyalty to the community's traditional character.

Key words: Popular Poetry, Ox, Herdsman, Identity Construction, Brazil.

${ }^{1}$ Gostaria de agradecer ao Prof. Dr. Ion Taloş (Universität zu Köln) pelos comentários ao texto, pelo apoio, e principalmente pelo exemplo.

RDTP, LVIII, 2 (2003): 33-70 


\section{OBJETIVOS DA ANÁLISE}

Eu tinha precisão de aprender mais, sobre a alma dos bois.

Os momentos iniciais da narrativa popular quase sempre apresentam o rompimento da rede de relações pessoais do herói épico. Ele fica órfão, é expulso de casa por uma madrasta má, se desencontra de sua companheira, se perde na floresta, é obrigado a fazer uma longa viagem, etc. Neste sentido, diríamos que ser herói tradicional significa estar sozinho durante um difícil percurso necessário àquele que busca ser reconhecido. Mas a solidão inicial dessa persona seria pura ilusão. Ao contrário do que poderíamos supor à primeira vista, o herói que se coloca no caminho que conduz à "grande prova" —em que pese seu isolamento— não é um "indivíduo". Em sociedades tradicionais, aquelas movidas por um indeclinável senso de coletividade, é extraordinário estar só. Mais que isso, é perigoso. Por isso o isolamento de seus heróis nunca é absoluto. Destituído de suas relações pessoais iniciais, o herói tradicional ganhará outras. Novas relações que se apresentarão sob a forma de um auxiliar conquistado através de valores (tais como lealdade, bondade, generosidade, obediência, boa vontade) que demonstrem a aptidão do herói para viver em comunidade.

Seguindo este raciocínio, poderíamos dizer que esse herói-que-nunca-estásó corresponderia à categoria de "pessoa", no sentido que Mauss e DaMatta dão ao termo: um sujeito moralmente atado a suas relações pessoais. Aquele que é o resultado da prevalência do conjunto sobre o particular; aquele que os outros reconhecem, e que reconhece os outros em si (Maffesoli 1996: 311). Sendo "pessoa", este herói se define por seu auxiliar. É o auxiliar que age naquela situação em que o herói supostamente deveria agir sozinho. Quem vem em seu socorro, como invariavelmente acontece no dia-a-dia dos membros da comunidade tradicional, são as suas relações pessoais. Portanto, as conquistas desse herói-pessoa nunca serão entendidas como absoluto mérito individual. Elas sempre serão frutos do demonstrar conhecimento de e respeito a valores constituídos coletivamente.

2 Augé (1995) já nos chamava a atenção para o problema do uso do conceito de indivíduo que parece sempre estar aquém ou além do que se pretende dizer. No caso, a palavra indivíduo foi empregada no sentido de DaMatta: o membro da sociedade individualista, da qual a essência é o pressuposto de igualdade dos sujeitos. Tal igualdade pretendida como valor absoluto submete o sujeito ao anonimato. Ou seja, ele não se define por suas relações (como acontece na sociedade tradicional), mas sim por sua individualidade. 
Sob a forma de um auxiliar, essas novas relações determinam aquele que fora o eleito para trilhar o caminho de herói e evitam que este seja visto como autodeterminado naquele momento decisivo da construção de sua identidade $^{3}$. É o auxiliar que age e garante ao herói o reconhecimento. Porque se o herói conta com um auxiliar isso significa que ele age conforme um padrão tradicional de ação ditado por sua comunidade. Reconhecê-lo, portanto, é participar de sua glória como se essa pertencesse a todos ${ }^{4}$. Por isso podemos dizer que o herói-Pessoa é, antes de tudo, plural. Nele tornam-se visíveis as duas dimensões que se encerram nos sujeitos da sociedade: aquele que deseja, simultânea e contraditoriamente, ser reconhecido tanto por sua singularidade quanto por sua de participação ${ }^{5}$. E é esse pluralismo que faz do herói tradicional um "tipo geral" no sentido de que a identificação dos membros da comunidade para com ele se torna possível.

Mas o que isso tudo tem a ver com os romances do ciclo do gado? No decorrer do trabalho poderemos ver como nessas histórias maravilhosas se encontra registrado o pluralismo que a noção de "pessoa" da comunidade de vaqueiros encerra ${ }^{6}$. Formada por homens guiados tanto pelo desejo de participação quanto pelo de autodeterminação, a comunidade de vaqueiros dramatiza nos romances táticas desenvolvidas coletivamente que permitem a recuperação para o grupo daquele que se "individualiza" durante a corrida desenfreada atrás do boi que todos acreditam encantado. Durante aquele momento excepcional de busca de reconhecimento, o vaqueiro, sujeito moralmente atado a suas relações pessoais, isola-se dos companheiros, se

\footnotetext{
${ }^{3}$ Mais que questão de oportunidade e habilidade individual, ser herói "tradicional" então passa a ser questão de destino. Para Augé (1995: 183), a estreita relação entre identidade e destino é que possibilita pensar o conceito de individualidade. No caso da narrativa tradicional, não há como questionar tal proposição.

${ }^{4}$ Segundo Augé (1995: 142), o equilíbrio tenso coletividade/individualidade se materializa na figura do herói. Este seria, ao mesmo tempo, tanto maximização e negação do indivíduo quanto maximização e negação da sociedade. Veremos que nosso vaqueiroherói e nosso boi encantado não são outra coisa.

5 Maffesoli (1996: 313) entende o auxiliar mágico, o anjo da guarda, o dióscure como recursos para se sublinhar o aspecto plural da noção de "pessoa" que o herói encerra. Seria esse plurarismo que permitiria que "o indivíduo se afirme como realidade autônoma, fechada e ao mesmo tempo como realidade participante".

${ }^{6}$ Falaremos em comunidade de vaqueiros (não em sociedade) no sentido de Tönnies (1926: 39), para o qual "se na comunidade as pessoas estão unidas apesar de todas as suas diferenças, na sociedade elas estão separadas a despeito de todas as suas ligações".

7 Por "individualização" entendemos o mesmo que DaMatta (1993: 109): independência temporária dos controles sociais do grupo de origem. No mesmo sentido Redfield (1941: 355), para o qual o processo de individualização se dá quando o indivíduo encontra possibilidades ou até mesmo incentivos para desprender-se da coletividade marcada por traços "coletivistas" e "age por conta própria".
} 
"despersoaliza", rompe momentaneamente a rotina de solidariedade que predomina entre os membros do grupo de trabalho. Experiências "individualizantes" que acabam por relativizar o determinismo das relações pessoais como única maneira de sobressair-se no espaço social, como única forma de reconhecimento da dignidade daqueles homens.

É nessa perseguição a um boi encantado que podemos ver em ação as facetas da noção de "pessoa" que sustenta a identidade da comunidade de vaqueiros, quais sejam: $1^{\underline{a}}$ ) o vaqueiro socialmente dependente de suas relações pessoais; $2^{2}$ ) o vaqueiro socialmente definido por suas habilidades individuais. Mas ao contrário do que poderíamos esperar de um pensamento classificacionista, o outro que rege a comunidade e o romance buscará em suas gestas formas de equação entre estes dois pólos. Trata-se de um tipo de pensamento que não pretende separar o individual do comunitário. Seja colocando nos textos um boi que fala com a comunidade e se define com relação aos seus vaqueiros, seja fazendo testamento do boi mandigueiro, seja construindo a fama de um vaqueiro-herói que pega "sozinho" esse marruá, as sucessivas "individualizações" dos personagens dos romances se converterão em desejo de fusão. Os companheiros se reconhecerão no boi ou no vaqueiro mais valoroso do sertão. $\mathrm{E}$ este reconhecerá em si sua comunidade. É organicamente que a comunidade de vaqueiros se apossa de seus sujeitos. O comportamento do vaqueiro, ao mesmo tempo que tende para uma exaltação do "eu", exalta o mundo de valores do qual ele participa. Neste ponto, a exaltação do "eu" coincide com a exaltação da comunidade ${ }^{8}$.

Os romances aqui analisados constroem-se registrando um processo de identificações sucessivas daquelas facetas do vaqueiro-Pessoa, sempre em conflito, sempre em diálogo. Depois das identificações, o imaginário coletivo as reúne em co-existência dinamicamente equilibrada, fundando pela comunhão (da honra do boi encantado ou do vaqueiro vitorioso) um modo de ser coletivo. Neste sentido, a superioridade individual se tornará honra coletiva', integrando feito particular e feito comum, vida particular e vida coletiva. O

\footnotetext{
8 (Morin 1997: 74, 75). Veremos portanto que o processo de individualização não é irreversível nem tampouco estaria ligado à idéia de desorganização da comunidade como vários estudiosos (inclusive Redfield) tendem a pensar. Entre os vaqueiros, as formas de comportamento "individualista" são tão costumeiras quanto o coletivismo. As mesmas são definidas e circunscritas por um mecanismo, que, reconhecido coletivamente, orienta as ações dos membros do grupo. O que significa que ambas as formas podem se distinguir como elementos estruturais daquela comunidade.

9 "En realidad no es una cuestión de ideas la que mueve a los hombres al pretenderlo [o reconhecimento que Caro Baroja chama valer más], sino un instinto nacido en individuos que se mueven dentro de estructuras sociales [...] El valer más, en efecto está ligado con una idea de la honra que no es individual, sino con una especie de honor coletivo [...]" (Caro Baroja 1964: 410-460).
} 
que não significará a abdicação da individualidade, mas sim, sua incorporação no sistema de relações. Ao final, tem-se a relativização dos critérios de diferenciação entre consciência coletiva e individual na consciência total de cada um dos membros da comunidade ${ }^{10}$.

A mensagem das variantes analisadas reforça o código moral tradicional e sanciona as normas e práticas sociais num resgatar-se contínuo do ser individualizado (seja ele vaqueiro ou boi). Neste processo, a natureza se apresenta como matéria simbólica servindo a razões sociais. Através do boi encantado ou do vaqueiro-herói, é possível ver como a uma inconsciência da necessidade de solidariedade ${ }^{11}$ sobrepõe-se o desejo de afirmação da individualidade dos sujeitos. Daí que boi encantado e vaqueiro não se opõem um ao outro naquele combate no sertão. Cada um dos personagens é, na verdade, metáfora da dualidade em si. Ambos comportam em si as duas facetas de uma mesma persona e dramatizam a luta que ali é de vaqueiro contra vaqueiro; este contra uma parte de si mesmo ${ }^{12}$. Ou seja, a fronteira entre consciência coletiva e consciência individual deve ser determinada, sim, no interior do sujeito social - no caso, o vaqueiro.

Porém, antes da análise propriamente dita, é preciso que façamos algumas considerações a respeito da nossa linha de interpretação. A partir da leitura dos trabalhos de Viveiros de Castro (1986) e Roberto DaMatta (1987 e 1990) nasceu o desejo de tentar identificar nos romances de gado o processo de construção da noção de "pessoa" da comunidade nos romances do ciclo do gado. Seguindo este objetivo, acabamos por construir uma espécie de "sociologismo" que deve ser justificado. No Brasil, o universo simbólico que envolve os romances de gado goza de uma certa inteireza. São textos que "evoluem" à medida que aquela comunidade discute sua identidade fazendo uso do seu estoque de símbolos para preservá-la, complementá-la ou alterála (Honko 1993: 19). Partindo da tradição oral, esses romances passam pelo cordel e acabam por desembocar na literatura erudita. Do "Rabicho da Geralda" à "Morte do Touro Mão de Pau", de Genésio a Arnaldo ${ }^{13}$, o tema do boi famoso

10 "Há, em cada uma de nossas consciências [...] duas consciências: uma que é comum ao nosso grupo todo, e que por conseguinte, não é nossa, mas a sociedade vivendo e agindo em nós; outra que, ao contrário, representa-nos naquilo que temos de pessoal e distinto, e que faz de nós um indivíduo" (Durkheim 1987: 82).

${ }^{11}$ Inconsciência no sentido que esta solidariedade é cotidiana e óbvia. Nas reuniões para contar suas aventuras é que os vaqueiros sentem esse pertencer, essa dependência constante e recíproca do grupo, que em tempo normal não seria sentida por estar desde sempre e inevitavelmente presente.

${ }^{12}$ No fundo —diz Augé (1995: 191)— cada um de nós sabe que não há uma cisão entre nossas peripécias individuais (psíquicas e somáticas) e nosso papel social.

13 A dissertação de mestrado da professora Enelita de Sousa Freitas nos propõe uma análise intertextual de três dessas narrativas, onde a autora identifica o que ela chama "ritual do boi" (Freitas 2000). 
que mexe com os brios de vaqueiros honrosos e obstinados passa por variações, cujos detalhes falam muito mais da atualização identitária da comunidade de vaqueiros do que se poderia imaginar à primeira vista. A dialética entre "realidade da vida cotidiana" e "realidade da vida inventada" — facilmente identificada entre o cotidiano da comunidade de vaqueiros e as gestas que eles produzem e "tradicionalizam" - salta aos olhos. Realidades múltiplas $^{14}$ que se revelam sob o olhar fenomenológico que procuramos adotar para a análise do nosso objeto. No caso dos romances não há que se falar em ficção no sentido puro da palavra uma vez que os próprios textos contituem em si, também, uma experiência do real. Esta não se limita ao aqui-agora do cotidiano daquela comunidade, mas sim opera nesse outro nível, o do romance, que é amplo e literalmente vivido pela comunidade narrativa. Essa multiplicidade de realidades nos chamou atenção e resultou na tentativa de outro tipo de interpretação.

Trabalhamos com dezessete variantes dos chamados romances de vaqueiros recolhidas da tradição oral e uma registrada no $\operatorname{cordel}^{15}$, nas quais o enredo gira em torno da perseguição e morte de um barbatão ${ }^{16}$. Os romances, vivos na tradição sertaneja brasileira desde o século XVII, contam as aventuras de inúmeros vaqueiros às voltas com um boi fujão, que, revoltado com o tratamento que recebe dos homens (ele é perseguido, ferrado e castrado), some no sertão ${ }^{17}$. Ali, "onde de repente falta solo ao cavalo e espaço ao homem" (Alencar 1959: 1150), sozinho e protegido na paisagem durante anos a fio, o bicho ganha fama incitando o velado desejo de ser reconhecido como herói nos vaqueiros de toda região. Estes, durante anos de perseguição, buscam seu triunfo frente ao boi que enfrenta os homens e muitas vezes sai vencedor. Até o dia de sua morte, que pode ser narrada de duas maneiras,

${ }^{14}$ Para Schütz (1979: 48-61) as realidades são múltiplas (realidade dos sonhos, do sobrenatural, da ciência,...), cada uma delas constituindo o que o autor chama provinces of meaning [Sinngebiete]. Cada uma dessas "províncias de sentido" possui seu próprio estatuto ontológico.

${ }^{15}$ As variantes se encontram relacionadas no Anexo III. Todas elas narram a morte do boi no final da aventura. Variantes em que o boi permanece vivo (na terra ou em um espaço metafísico) exigiriam, a meu ver, uma complementação da análise em uma outra oportunidade.

${ }^{16}$ Barbatão é o nome que se dá ao boi criado à solta no sertão. É sinônimo de marruá.

17 O enredo de todos os romances de bois analisados gira em torno do esforço para trazer o boi fujão de volta à esfera habitada, "civilizada". Para conseguir realizar tal tarefa, o vaqueiro acaba por afastar-se da "civilidade", do grupo e isolar-se também no sertão, o espaço selvagem, aberto à individualidade extremada. Esse desencadear de individualidades que pudemos verificar nas variantes esclareceriam, em parte, a preferência pelo tema épico nesses casos. 
cada uma delas formando um subgrupo de narrativas. No primeiro, as variantes são autobiográficas. Quem narra toda a aventura é o boi, narrador onisciente. Nestas variantes, o boi morre pelas mãos de muitos vaqueiros ou nos dentes de cães ferozes. Através da ação marcada pela coletividade, identifica-se mais facilmente a ameaça direta e o caráter inevitável da morte do boi, que neste caso é o herói da narrativa. No segundo subgrupo, a narração é feita em terceira pessoa. O boi é vencido por um só homem e o que orienta a narrativa é a necessidade de ação desse herói isolado, o vaqueiro ${ }^{18}$.

\section{A COMUNIDADE DE VAQUEIROS}

Conbece-se o boi pelo chifre e o bomem por suas ações.

(Provérbio Popular)

Para o vaqueiro, vestir-se como boi é uma honra. O orgulho que este homem tem de sua profissão se revela no valor que ele dá a sua roupa (um gibão de couro de boi), a seu cavalo, a seus amuletos, à suas rezas, enfim, ao conhecimento de toda uma tradição profissional da qual um vaqueiro considera-se digno herdeiro. Essa identificação do homem com os símbolos de sua profissão revela o peso que o reforço de papéis sociais tem para os sujeitos de uma comunidade de tipo tradicional. A roupa e o cavalo do vaqueiro determinam-no como ser social ${ }^{19}$. Uma identidade da qual - segundo Capistrano de Abreu (Menezes 1995: 39) (em que pese todo seu preconceito)- o vaqueiro se orgulhava e muito.

Nos sertões da Bahia, Pernambuco e Ceará, principalmente pelas vizinhanças do São Francisco, abundam mulatos, mestiços e pretos forros. Essa gente perversa, ociosa e inútil, pela aversão que têm ao trabalho de agricultura, é muito diferentemente empregada nas fazendas de gado. Tem a esse exercício uma tal inclinação que procura com empenho nele ser ocupada, constituindo toda sua maior felicidade em merecer algum dia o nome de vaqueiro.

${ }^{18}$ Nos anexos I e II segue uma variante-exemplo para cada um dos subgrupos.

19 No cordel "O Boi Mandigueiro e o Cavalo Misterioso" de José Bernardo da Silva, o vaqueiro-herói Genésio deixa claro seu orgulho para com a identidade social que seu gibão the confere. No dia de seu casamento, se recusa a vestir a roupa do pai de sua noiva, a filha do fazendeiro. Sua armadura de couro lembra-lhe de seu dever de reciprocidade para com os seus. Mais que se casar com Leonor, tirar seu gibão (ou vestir a roupa de fazendeiro) é que representaria o rompimento de suas relações anteriores. Neste sentido pode-se dizer que a roupa faz relações. O que Genésio deseja é o equilíbrio entre extremos. Uma opção pela identificação com um dos pólos comprometeria a natureza inclusiva, correlacional — por isso eficaz- do instrumental simbólico utilizado nos romances. 
A profissão de vaqueiro e a conquista sempre andaram juntas na história do Brasil colonial (Viana s.d.: 60-62). O pastoreio serviu à necessidade de povoação nos primeiros tempos da colonização e como degrau de ascenção social àqueles marginalizados pela cultura litorânea. Os vaqueiros representavam o limite; tinham que enfrentar índios, negros em fuga, bandidos: toda uma leva de marginalizados que encontrava no sertão um abrigo. Condições ${ }^{20}$ e o local de trabalho ligavam reciprocamente os vaqueiros numa interação que se fazia essencial ${ }^{21}$. O sertão perigoso (por sua natureza e pelos homens que ali se abrigavam), espaço-limite, não escondia o risco de vida para aquele que ousasse tentar domá-lo ${ }^{22}$. Trabalhar em grupo neste caso significava maior produtividade e segurança ${ }^{23}$.

A marginalidade a que se submetiam os vaqueiros dos séculos XVII até início do século XIX, ao mesmo tempo que os manteve separados da "civilização", permitiu que esse mesmo grupo acabasse desenvolvendo um estilo de vida próprio, o que pressupunha uma relativa autonomia. Isolados ali, eles determinavam as regras do trabalho, recebiam em espécie, trabalhavam sem vigilância e fiscalização de "estranhos", afastados do controle direto do patrão que vivia no litoral. Para ser vaqueiro, ou seja, expor-se ao perigo, ao risco de vida, mais que ser solidário era preciso ser corajoso, valente, honrado ${ }^{24}$. Ingredientes de herói. Ser vaqueiro significava, portanto, poder vir a ser herói, um dia ser respeitado por algum feito que se realizou sozinho. Participando cotidianamente dessa vida perigosa, a individualidade desses homens

20 "O vaqueiro [...] achou-se em face de um sertão imenso e de grandes manadas de gado, esparsas pelo campo. Este sistema de criação, inteiramente diverso do europeu, obrigava o homem a uma luta constante" (Alencar 1960: 963).

${ }^{21}$ Como na comunidade caipira analisada por Franco (1976: 33-37), o vaqueiro "era induzido à cooperação num processo de favorecimento da coesão interna do grupo profissional".

22 "O risco de morte [...] implica sempre uma presença e uma riqueza de participações” (Morin 1997: 73).

${ }^{23}$ Os vaqueiros recebiam em espécie. Portanto, quanto mais bois pudessem juntar numa vaquejada, maior seu ganho. Uma necessidade a nível prático que o vaqueiroherói do romance nega, revelando valores de sua comunidade. Ele trabalha antes de tudo por sua honra de vaqueiro! Quando o patrão fala em dinheiro a ser pago pelo marruá, o vaqueiro desconsidera a recompensa num discurso que deixa claro que a riqueza não é para ele o primeiro predicado observado para ser respeitado pelos outros. A valentia, honrar a palavra empenhada, não fugir ao desafio são as qualidades mais admiráveis.

${ }^{24}$ Morin (1997: 71, 72) descreve como o risco de morte promove o indivíduo. Este acaba por autodeterminar-se através de seus próprios recursos de vontade para poder vencer seu medo e garantir sua honra, seu prestígio, sua dignidade. 
ganhava força ${ }^{25}$. O contexto era portanto propício ao desenvolvimento dessas individualidades. Uma consciência de si que conferia àqueles homens a garra e a coragem para que pudessem enfrentar a luta cotidiana e garantir o triunfo de toda a corporação.

Contraditoriamente, esse mesmo espoucar de individualidades acabava por desfavorecer a coesão do grupo. A qualidade comunitária da atividade que os vaqueiros exerciam não era o bastante para assegurar a "cooperação irrestrita". Ser o vaqueiro mais famoso da região passava a ser a grande ambição. Instaurava-se assim a competição. Esse componente de ruptura que integrava o sentido das relações do grupo profissional ${ }^{26}$ era realçado quando surgia um boi que ninguém conseguia pegar. Um boi de fama, encantado, digno de ser caçado por um verdadeiro Teseu. Era o momento de saber quem era o melhor. Os vaqueiros começavam a medir-se, num processo de autoafirmação. Pegar o boi mais famoso da região, que desafiava o homem "em suas barbas", passava a ser questão de honra, coragem e "firmeza". Por isso, a atitude do vaqueiro (que o romance atribui também ao boi) deveria fazer jus ao apreço de sua gente pela valentia, pela honra, pela palavra empenhada. O homem, que se sentia desafiado em sua capacidade profissional e conseqüentemente em sua integridade, o homem que não tolerava dúvidas quanto a seus atributos pessoais, ousava então entrar no sertão sozinho. Declarava sua auto-suficiência perseguindo o boi, a fama, enfim o boi-Fama.

Euclides da Cunha registrou o momento em que esse homem de relações rompia com o grupo por culpa de um boi famanaz. Solidários todos os vaqueiros auxiliavam-se "incondicionalmente em todas as conjunturas". Se fugia algum "boi levantadiço", o vaqueiro saia em seu encalço. E se não tivesse sucesso, pedia ajuda "aos companheiros mais vizinhos", e lá seguiam eles, "aos dez, aos vinte, rápidos, ruidosos, amigos" até que "o bruto" se cansasse da corrida ou tombasse diante da força do grupo. Porém, a solidariedade de esforços que o autor acreditava evidenciar-se nas vaquejadas ${ }^{27}$, era relativizada exatamente nesse momento. Quando surgia a possibilidade de pegar o boi

25 "A individualidade não se dissolve, mas adere às, se identifica com forças, com realidades que a exaltam. Auto-afirmação tanto mais rica porque o herói nunca se sente tão fortemente ele mesmo como no momento do perigo" (Morin 1997: 74, 75).

26 "Em resumo, a análise da natureza e da ordenação das relações que se estabelecem em grupos de trabalho, em um sistema social de tipo comunitário, revela a existência de um estado de tensão conjugado às formas mesmas de solidariedade que definem o sentido da ação de seus membros" (Franco 1976: 36).

${ }^{27}$ Reunião do gado (criado em pastagens indivisas) no fim do inverno para que pudesse ser marcado com os ferros de seus donos, tratado dos ferimentos e castrado. Logo depois era feita a apartação: entrega dos animais aos seus donos e separação dos animais dados em pagamento ao vaqueiro. 
terror da região, o sistema de relações se tornava maleável e deixava uma fresta por onde viam-se as relativas vantagens de se estar livre do compromisso com o grupo. Por essa fresta saía, como um gênio, o sujeito em busca de sua auto-afirmação, do espaço para sua individualidade. Na caça ao marruá, a ascensão social do vaqueiro estaria subordinada menos a suas relações e mais a suas habilidades individuais. Por isso, aquele que precisasse correr atrás do boi acreditado encantado não pensava duas vezes: ele faria o que nenhum dos seus fora capaz de fazer. Venceria o boi famanaz sozinho.

Entretanto, como o boi desgarrado que volta para o gado formando junto com os outros um bicho inteiro, o vaqueiro também voltava. Contava a façanha aos companheiros agitados para saber detalhes da aventura que os arrancava da rotina. Os companheiros contavam outras idênticas. As impressões heróicas eram trocadas, contagiando a todos os cavaleiros que juntos voltavam a ser também um "organismo" só: a comunidade de vaqueiros. Eram repartidos, num banquete para todos, a glória do vaqueiro-herói e o marruá morto por ele. Na comunhão, o vaqueiro se afirmava como sujeito ao mesmo tempo autônomo (fechado) e participante (aberto). Depois da regressão do nível de coesão interna do grupo (proporcional à promoção do indivíduo autodeterminado), a fusão. Um só e mesmo fenômeno que fundamenta a consciência identitária do vaqueiro e, portanto, de sua comunidade.

Vemos que, se por um lado o vaqueiro vivia imerso na pessoalidade das relações, das participações, por outro, em determinados momentos do exercício de seu trabalho, ele vivia a possibilidade de desenvolver sua individualidade. A solidariedade, o senso de coletividade que orientavam as ações do vaqueiro, se apequenavam diante do boi famanaz. Para correr esse boi, o vaqueiro revelava-se menos inclinado a ser como os outros, a ser para os outros. Sabia que seria reconhecido, menos por suas relações que por sua singularidade. Dentro de uma esfera de ação própria, o vaqueiro acabava por demonstrar que a unidade de seu grupo era diferenciada e competitiva. $\mathrm{E}$ era naqueles lapsos da pressão do sistema de relações que a auto-afirmação encontrava espaço de expressão. Assim, individualidades e comunidade eram reconhecidas como categorias em correlação. Se por um lado o objetivo principal do vaqueiro é o reconhecimento, se o que almeja é um lugar no pensamento dos outros, em troca, o que ele oferece é "fidelidade aos padrões comuns de respeito e normas de agir" (Cooley 1987: 81-82).

Um processo que pode ser identificado também nas festas dos vaqueiros onde ocorriam as competições de derrubada de gado. A festa de vaqueiros era "o cenário conveniente às afirmações de supremacia e destemor, a oportunidade para a realização de façanhas perante a audiência numerosa e que tem em alta conta o valor pessoal" (Franco 1976: 38). Ali, a cobrança do grupo para com o indivíduo é evidente: o que vaqueiro mais teme é ser 
desonrado aos olhos dos companheiros, é ser chamado de covarde. Por outro lado, a festa de vaquejada era também o espaço das emoções compartilhadas $^{28}$. O momento em que todos os cavaleiros professavam o orgulho de ser vaqueiro comungando da glória de apenas um dos companheiros ${ }^{29}$. O ciclo se fecha portanto: o reconhecimento do indivíduo acabava por reforçar o sentimento de corporação, o orgulho de pertencer à comunidade de vaqueiros. O que se vivia naquelas festas era, em essência, uma partilha de satisfações entre grupo e indivíduo, o que resultava na "identidade total" da comunidade ${ }^{30}$.

Aqui faz-se necessário o esclarecimento quanto ao que chamammos "comunidade de vaqueiros". Ali, sertão aberto e sem divisas, viviam os vaqueiros vistos por Euclides da Cunha (1933: 123) "com suas vestes características, os seus hábitos antigos, o seu estranho aferro às tradições mais remotas, exagerado ponto de honra e seu folclore belíssimo de rimas de três séculos". Uma comunidade que "não quer o indivíduo ocupando - exceto em situações excepcionais - um papel central em sua dinâmica, mas aquele que seu estatuto social lhe reserva"31. O homem dessa comunidade vive enredado em suas relações pessoais. Há os laços entre os vaqueiros, que sólidos, fazem com que o grupo de companheiros de trabalho pareça agir como uma unidade dentro da comunidade mais ampla. O grupo profissional se auxilia e compartilha do mesmo código de conduta. Há também os laços que envolvem vaqueiros e patrões; estes hierarquicamente comprometidos uns com os outros conforme direitos e obrigações bem definidos, que se garantiam sob aquele mesmo código de honra e lealdade ${ }^{32}$.

Para aqueles homens a aliança era algo que se impunha irrecorrivelmente. Alianças que constrangiam o sujeito de diversas maneiras e exerciam sobre ele uma pressão constante (Slater 1984: 230-255). Dado o contexto, fica fácil entender porque aqueles homens estavam sempre em busca do reconheci-

28 "Algunas fiestas taurinas, mas que ese paisaje agonístico, parecen pensadas para ilustrar las dualidades y el tránsito entre sus extremos" (Calavia 1997: 161).

29 "A glória é exaltação da vida individual que, ao mesmo tempo, permanecerá na memória coletiva. É o que torna a identidade coletiva ambivalente" (Morin 1997: 46).

${ }^{30}$ É nas festas de vaqueiros, participando do lúdico e do moral ali envolvido, que "se afirma o indivíduo, mas afirma-se também que as participações valem o sacrifício eventual de uma individualidade" (Morin 1997: 47).

31 "O que é valorizado neste tipo de sociedade não é o indivíduo-cidadão, mas sim as relações" (DaMatta 1987: 26).

32 Por isso, mais que empregado, o vaqueiro era do patrão. Aquele que pegasse o marruá teria seu triunfo dividido com o patrão. Afinal, quem pegara o boi encantado fora "uma criatura sua". Proezas de animal e vaqueiro contavam "entre os brasões de sua fidalguia sertaneja" (Alencar 1959: 1139). 
mento: este equivalia a novas possibilidades de relações. Era através da rede de relações pessoais que vaqueiro e comunidade pensavam e organizavam seu mundo, seu espaço social. Somente ao abrigo desse código a pessoa poderia crescer e exprimir suas diversas potencialidades sem perturbar $\mathrm{o}$ estado de coisas. Euclides da Cunha (1933: 123) nos ilustra bem este "cadacoisa-em-seu-lugar" que o código dos vaqueiros estabelecia.

O fazendeiro dos sertões vive no litoral [...]. Os vaqueiros são-lhes servos submissos. Graças a um contrato pelo qual recebem certa percentagem dos produtos, ali ficam, anônimos — nascendo, vivendo e morrendo na mesma quadra de terra [...] e cuidando fielmente, dos rebanhos que lhes não pertencem. O verdadeiro dono, ausente, conhece-lhes a fidelidade sem par. Não os fiscaliza. Sabe-lhes, quando muito, os nomes. [...] Quando surge no seu logradouro [do vaqueiro] um animal alheio, cuja marca conhece, o restitui de pronto. No caso contrário, conserva o intruso, tratando-o como os demais. Mas não o leva à feira anual, nem o aplica em trabalho algum; deixa-o morrer de velho. Não lhe pertence.

O que o autor de "Os Sertões" chama de "servidão inconsciente" revela a preocupação do vaqueiro com a palavra dada, com a honra, com a lealdade. Lealdade recíproca que o pesquisador observou na natureza dos contratos entre vaqueiros e seus patrões naqueles sertões de antigamente (Cunha 1933: 124, 124). Se uma vaca, cujo sinal não era reconhecido pelo vaqueiro dava cria, este marcava a cria com aquele mesmo sinal.

De quatro em quatro bezerros, porém, separa um para si. É a sua paga. Estabelece com o patrão desconhecido o mesmo convênio que tem com o outro. E cumpre estritamente, sem juízes e sem testemunhas, o estranho contrato, que ninguém escreveu ou sugeriu. [...]. Parece fantasia este fato vulgar, entretanto, nos sertões. Indicamo-lo como traço encantador da probidade dos matutos. Os grandes proprietários da terra e dos rebanhos a conhecem. Têm, todos, com o vaqueiro o mesmo trato de parceria, resumido na cláusula única de lhe darem em troca dos cuidados que ele despende, um quarto dos produtos da fazenda. E sabem que nunca se violará a porcentagem.

Mas, ao contrário do que possa parecer, coronel e vaqueiro não confiavam um no outro como "indivíduos". Apenas faziam o que deviam: permanecer leais a "noções veneráveis" de como deveriam funcionar os relacionamentos entre os sujeitos na comunidade tradicional (Slater 1984: 236, 237). Não podemos falar, neste caso, de homogeneidade da lei, como aquela existente no sistema legal de uma sociedade que é ou se pretende individualista. Está longe daqui aquela impessolidade essencial à aplicação da lei dos códigos atuais. Vaqueiros não são "todos iguais" aos olhos de seu patrão, assim como os bois não são anônimos para seu vaqueiro. Se cumprir aquele contrato sem letra é questão de fidelidade, relativizar a norma frente às particularidades de cada um é questão de reconhecimento. 
Naquele mundo tradicional, não haveria como negar que a "palavra" —esse valor altamente pessoal- constituía um componente importantíssimo nas relações entre os sujeitos. Ela era a medida da qualidade das relações pessoais à qual estava submetida a estabilidade do vaqueiro como membro da sociedade. Valores como honra, lealdade, deferência, solidariedade e reciprocidade agiam num processo de supra-ordenação do espaço social. Esses valores morais, que o sertanejo resume na palavra "firmeza", cumpriam, portanto, um papel importante demais: faziam com que a hierarquia parecesse natural. Era através deles que se colocava cada coisa em seu lugar em uma sociedade que ainda não contava com a letra fria da lei. Neste sentido, podemos dizer que a palavra mantida era ali uma instituição.

Por causa desses valores enraizados era que, em vez de preterido, o vaqueiro que pegava o boi encantado sozinho era acolhido por seus companheiros. Um reconhecimento que recuperava para o grupo o sujeito que havia se "isolado". Ser o vaqueiro que pegou o barbatão, do qual não se davam notícias há anos, trazer de volta o patrimônio do fazendeiro, significava deixar de ser um vaqueiro e passar a ser $o$ vaqueiro. A obrigatoriedade do trabalho conjunto se rompia ao galope do vaqueiro atrás do boi da fama, mas porque o status denotava relações pessoais ${ }^{33}$. Transformado em celebridade, o vaqueiro passava a ser respeitado por todos. Solidários, a glória de um alcançava todos os companheiros ${ }^{34}$. $\mathrm{O}$ vaqueiro-herói era transformado em um modelo que condensava todo um modo-de-ser elaborado coletivamente ${ }^{35}$. Transformado em "tipo ideal", o vaqueiro permitia a participação "mágica" de cada um de seus companheiros no seu feito. O que se fazia no caso dessa identificação era postular um mundo regido por aqueles valores. Um mundo que tinha "la entidad de una densa red de relaciones, pero también la entidad de unos símbolos compartidos" (Velasco 1980: 106).

E o que acontecia com o vaqueiro acontecia também com o boi que criava fama na região. Ele também era visto como objeto de identificação. O que podia ser comprovado a partir da relação pessoal que os vaqueiros mantinham com "seus" animais. Ainda hoje, falam deles com afeto ${ }^{36}$. Chamam os

33 (Bogardus 1987: 133) Possuir maior status significava possibilidades de identificações, de participações —ou seja, de relações- e, através delas, uma maior mobilidade e conforto dentro do sistema social.

${ }^{34}$ Interessante que o romance não mencione o sentimento de inveja. O que não quer dizer que tal sentimento - humano demais que é- não existisse. O que nos leva a crer que tal sentimento não deveria aparecer. Manifestá-lo seria romper o pacto quanto ao reconhecimento daquele destinado a herói.

${ }^{35}$ A sedimentação dos valores que são transmitidos de uma geração a outra "opera a valorização de atitudes típicas". Acaba-se por construir modelos que suscitam identificação (Maffesoli 1996: 327).

36 "Eu gosto de bois, Manico, ponho amor neles" (Rosa 1983: 36). 
animais de "meu boi", "meu boizinho", "camarada"37. Pelos sertões do Brasil encontram-se ainda hoje vaqueiros que conhecem de memória o nome de "seus" animais, seus respectivos caprichos e manias ${ }^{38}$. Falam de cada um como se fala de alguém que se conhece muito bem. Seu Chiquinho mesmo esclareceu-me o que se pensa de cavalos e bois no sertão da Minas Gerais de hoje: "Aqui falamos de boi e cavalo como se fala de gente"39.

Euclides da Cunha (1933: 127) descreveu como o componente afetivo (ou seja, relacional) pesava na relação do homem para com seus bois. Em meio ao gado que levava ao mercado, o vaqueiro considerava, ali um velho boi que ele conhecia há dez anos e nunca havia levado à feira, "mercê de uma amizade antiga". Porém, no mesmo grupo, mais adiante, "cabeça alta e desafiadora, seguindo apenas guiado pela compreensão dos outros" caminhava o touro inveja de toda redondeza. Soberbo, ele seguia folgado porque os demais o respeitavam, "abrindo-lhe em roda um claro". Difícil saber se é a gente que cria o gado ou se o gado é que cria a gente. A identificação parece bem mais profunda. Como o boi voltava sob o jugo do braço do vaqueiro para o meio do gado manso, o vaqueiro também voltava para os seus sob a pressão do sistema de relações que sustentava sua comunidade. Mas o cavaleiro (como aquele segundo boi) voltava de cabeça alta e desafiadora seguindo apenas guiado pela compreensão dos companheiros, que entendiam $\mathrm{o}$ apreço que o vaqueiro tinha por sua fama e lhe abriam em roda um claro. $\mathrm{Na}$ verdade, vemos que "o homem é menos criador de imagens que forjado por elas" (Maffesoli 1996: 150).

Essa identificação entre homem e boi se dava nesse entrecruzamento de relações que acontecia na rotina de trabalho e nas aventuras que os dois viviam no sertão ${ }^{40}$. Correr às cegas pelo mato fechado atrás de bois criados livres era a façanha admirável do sertanejo. Era como se os bois selvagens

37 Expressões que, nos romances, possuem correspondentes invertidas revelando que o boi também trava relações com seu lugar, com seu patrão e seus vaqueiros. Ao narrar sua biografia, o boi chamará o sertão de "seu", "minha terra", "minha serra", mas também seu dono de "meu amo", "meu senhor" e seu algoz de "meu vaqueiro". No mundo do romance, bois e homens se pertencem mutuamente.

38 Uma intimidade que chamou a atenção do historiador Euclides da Cunha (1933: 123, 124) que anotou: "[...] o vaqueiro, não se contentando com ter de cór os ferros de sua fazenda, aprende os das demais. Chega, às vezes, por extraordinário esforço de memória, a conhecer uma por uma, não só as rezes de que cuida, como as dos vizinhos, incluindo-lhes a genealogia e hábitos característicos, e os nomes, e as idades, etc.”.

39 Sr. Chiquinho, 46, casado, vaqueiro no lugarejo chamado Maquinezinho, distrito de Cordisburgo, Minas Gerais; julho/2000.

${ }^{40}$ Callois (citado por Morin 1997: 96) já havia observado que "o comportamento real de uma espécie animal pode aclarar as virtualidades psicológicas do homem". 
estivessem constantemente a desafiar os vaqueiros em sua honra. O homem porém olhava para o boi como se este fosse um igual. $\mathrm{O}$ animal era visto como companheiro, e por isso também leal e conhecedor daquele mesmo código de conduta do sertanejo ${ }^{41}$. Animal e homem deveriam ser bravos, nenhum deles jamais renegaria um desafio. Afinal, o bom vaqueiro honra sua palavra e faz sempre o seu trabalho. Um fazendeiro-vaqueiro de Guimarães Rosa (1983: 37) é quem diz: "o que eu entendo das pessoas, foi com traquejo dos bois que aprendi”. E são de Arnaldo, o arquétipo do vaqueiro leal, as palavras: "nunca menti a homem, quanto mais a boi" (Alencar 1959: 1156). $O$ vaqueiro via-se no boi livre, solto, que tinha que ser domado e trazido de volta pro meio do gado manso. Como o boi, de tempos em tempos, ele também era como que domesticado e obrigado a voltar ao mundo das relações. Na verdade, se o vaqueiro condenado a suas relações era hỉbrido como um centauro, o boi era visto como um minotauro; híbrido também.

O boi encantado não é, portanto, uma "invenção" do romance. Ele era uma realidade na comunidade de vaqueiros. $\mathrm{O}$ boi que homem algum conseguia subjugar era cercado de atributos fantásticos e chamado Mandigueiro, Misterioso, Calundu, Feiticeiro, Mocambeiro. E fosse nas expedições para reunir o gado, fosse na festa (e portanto, no romance também), ele era o pivô de toda ação. Afinal, o boi mais valoroso do sertão o era graças à proteção de um homem, um vaqueiro-feiticeiro. Era chamado boi apadrinhado - aquele que tem como protetor um feiticeiro ou alguém pactuado com o diabo. Portanto, a luta contra esse boi encantado camuflava uma medida de forças entre os próprios vaqueiros. Para segurar esse bicho, só sabendo encantamento e feitiço maior do que aquele que possuia o padrinho. Lutar contra o boi mais famoso da região era, portanto, lutar contra outro vaqueiro. Ao fim, todos deveriam saber qual era o mais forte. Forte não somente no plano especificamente humano, social (competência profissional), mas também no plano da "sobrenatureza".

Parte do cotidiano, esse boi fantástico era real aos olhos do sertanejo que não concebia um abismo entre natureza e "sobrenatureza", entre homem e animal, entre sagrado e profano - c como veremos-, nem entre individualidade e comunidade. Seu pensamento era regido por uma lógica contextual que considerava tudo como parte de um todo, no qual cada coisa encontra

${ }^{41}$ Guimarães Rosa (1983: 3-68), o escritor-etnógrafo mineiro, registra em seu conto "O Burrinho Pedrês" vários momentos dessa lealdade recíproca boi/vaqueiro. Lá podemos encontrar os bois que chifram à traição seus companheiros bovinos e humanos; os bois-vaca — como são chamados os bois (tidos por covardes) que aceitam submeter-se à manada-; bois como Calundu que não batia em gente a-pé, mas gostava de correr atrás de cavaleiro. No imaginário da comunidade de vaqueiros, o código do sertão é adotado também pelos bois. 
sempre seu lugar. Ser vaqueiro era, portanto, viver em um mundo que ainda não havia renegado o sobrenatural aos confins. Sua comunidade encontrava-se totalmente contaminada de "sobrenatureza". Contra ela não se manifestava estranhamento, nem a ela se delimitava o espaço de ação. A dimensão onde se encontrava a comunidade de vaqueiros era única. Daí a condição de vaqueiro-feiticeiro. Um homem, profissional habilidoso, que conhecia os segredos dos animais, do sertão fossem eles segredos imanentes ou transcendentes.

O BOI ENCANTADO

Pra boi macumbeiro não tem vaqueiro.

(Provérbio Popular)

Os romances que analisamos repetem toda essa estrutura social. Neles coexistem tensamente equilibrados aqueles dois tipos de força que se movimentam no interior da comunidade de vaqueiros: uma centrífuga -movida pela consciência coletiva, pelo compromisso com as relações, pela determinação recíproca das vontades - e outra centrípeta, movida pelo anseio pelo reconhecimento da individualidade, pela vontade particular ${ }^{42}$. Através de uma transposição dos elementos do domínio do cotidiano para o simbólico, a comunidade de vaqueiros repetirá essa rotina de equilibrio nas gestas analisadas. Tomando fatos e imagens do espaço doméstico dos vaqueiros, o romance registra a tensão entre aquelas duas forças e a (con)fusão dos limites de ação do "ser-individualizado" com os do "ser-coletivo". No final da narrativa (repetindo a vida real), boi encantado e/ou vaqueiro-herói devem voltar. Cada um com sua fama, esta que faz deles heróis, únicos, ao mesmo tempo que reforça a união do grupo reforçando neste o orgulho de corporação.

E era na festa que a comunidade reencontrava esse seu talento para simbolizar expresso nos romances. Como os poemas, a festa encerra o poder de reativar a mentalidade épica que fundava aquela comunidade. No tempo de reunião dos vaqueiros depois do trabalho ou na festa, a comunidade redescobria esse seu "dom" conciliador. Aqueles eram os espaços do "sercoletivo" onde a individualidade era impelida para a alteridade e se constituía como tal (Maffesoli 1996: 92). Em meio a esse compartilhar-sentidos, a individualidade era englobada ${ }^{43}$. As variantes analisadas encenam exatamente

42 Maffesoli (1996: 122) chama atenção para a força centrífuga da experiência partilhada. Esta permite a religação social num movimento que favorece a identificação, ao contrário da outra (força centrípeta), que tem por alvo a identidade.

${ }^{43}$ A festa promove a mobilização dos sentidos e esta -a seguir Maffesoli (1996: 81) — possibilita união à alteridade. 
esse processo de reintegração. $O$ processo parece fantástico demais. Mas na verdade, os romances repetem o que as reuniões festivas dos vaqueiros já faziam $^{44}$. Em ambos os casos, trata-se de um estado de fusão que recobra o momento fundador da comunidade de vaqueiros quando cavaleiros conquistavam o sertão há três séculos.

Sendo assim, o tempo do romance é o do mito na medida em que se focaliza um momento vivido que, no espaço do imaginário, é convertido em uma espécie de realidade última. Ao passo que essas gestas parecem surgir da força criativa e "criadeira" das imagens compartilhadas no espaço doméstico é através da linguagem simbólica dessas mesmas narrativas que se realça o significado do cotidiano da comunidade. Uma rotina de relações dos homens entre si e destes com seus animais. O eixo da narrativa é um boi, o animal que evocava naquela comunidade uma emoção coletiva, o sentimento de participação comum na mesma Lebenswelt. Afinal, a vida da comunidade se concentrava em torno daquele bicho, fonte de alimento e de riqueza, motivo pelo qual se arriscava a vida. Porém, se por um lado podemos dizer que há uma certa razão ecológica na escolha desse animal como símbolo, por outro não podemos nos esquecer de que tal escolha se guia também por outros objetivos bem menos imediatos. Como vimos, o homem se identificava com o boi. Via na rotina de vida animal sua condição humana. No meio da multidão movediça de bois ou de homens havia tanto boisvaca e bois encantados, quanto vaqueiros anônimos e vaqueiros-heróis ${ }^{45}$.

Esquecendo a multidão, o romance volta sua atenção para aquele personagem do cotidiano que, num primeiro momento, resistia à vida de gado: aquele que queria ser reconhecido por seu valor individual, aquele que agia por si e para si somente. No caso das narrativas autobiográficas esse que se destaca do grupo, esse "outro" é um boi encantado. Incapacitado de reproduzir-se enquanto categoria social ${ }^{46}$, o boi do romance é boi-sozinho. O animal que faz fama, que é único, que possui honra e vontade própria, por um momento (não mais que o conveniente), será a imagem invertida da alma do vaqueiro preso à teia de relações (o "ser-coletivo"). Por isso, o boi mandigueiro é relegado a um espaço liminar. Nesse isolamento o marruá encarna a condição de perigo que enfrenta aquele que é privado da influência de suas relações. Ali, isolado no sertão, ele será o "outro", o "ser-individu-

\footnotetext{
44 "Em todas as sociedades humanas — nos diz Leach (1978: 46) - a grande maioria das ocasiões de cerimônia constitui-se por ritos de transição, que marcam o cruzamento do limite entre duas categorias sociais".

${ }^{45}$ Fazendo nossas as palavras de Calavia (1997: 162), diríamos que o boi livre do sertão antigo "no se convierte en símbolo porque sea feroz, sino porque vive lejos, en los límites: su bravura es así deseada".

${ }^{46}$ Sob essa ótica podemos ver a castração do boi de outra maneira.
} 
alizado". Óscar Calavia (1997: 156) identifica e nos esclarece com mais eficiência essa função de introdutor da alteridade que o barbatão encarna:

El toro [...] comparte sus funciones con animales más salvajes y más domésticos que él [...] Unos y otros unen el papel de oponente y el de auxiliar. Esa movilidad de los caracteres permitirá introducir contrastes en el mundo cultural, postulando la "bestialidad" de algunos aspectos de la organización social, e identificando modelos sobrehumanos en el mundo animal.

Mas como o isolamento do herói tradicional não deve, em princípio, ser absoluto, o boi-sozinho também cairá em contradição quanto ao seu desejo de individualidade. Sua condição de ser-isolado sofre uma regressão no decorrer das narrativas autobiográficas confirmando a necessidade da co-existência das dimensões ser-para-si/ser-para-o-grupo. Uma regressão que expõe aquela pluralidade da noção de pessoa que orienta a comunidade. Noção de pessoa encarnada no boi das variantes autobiográficas. É por isso que apesar de seu isolamento, o boi não tem como ignorar o imperativo da sobrevivência do grupo: ele fala o tempo todo ${ }^{47}$. Falante, o boi-sozinho toma a iniciativa de buscar relações ${ }^{48}$. Parece contraditório, e, na verdade, é. Acontece que o boi das variantes autobiográficas está na encruzilhada do comércio entre indivíduo e comunidade. Apesar de sempre ter fugido aos vaqueiros, conhece bem a comunidade deles e seu código social. Sabe que relações são necessárias a sua sobrevivência. Afinal, ele é apadrinhado: a força mágica de um vaqueiro é sua guardiã.

O boi alega em sua defesa os motivos (mais que justos) de seu isolamento e passa a definir-se por meio de todos os vaqueiros que derrubou. Legitima o nome dos vaqueiros lembrando o nome que vai deixar. Demonstra que conhece os homens que o perseguem, que de certo modo, sempre esteve às voltas com eles. Deixa claro que foi assim, derrubando vaqueiros,

47 É a necessidade de se contar a história que se permite ser o que é. Segundo DaMatta (1990: 209), a operação biografante procuraria superar a lei (que é geral) "precisamente pela invocação do dado pessoal". A fala do boi, ao mesmo tempo que nomeia -isto é, isola, distingue - num sentido inverso evoca subjetividades e permite veicular afetividades.

${ }^{48} \mathrm{Em}$ todas os romances analisados, cabe ao ser-isolado - seja ele o boi falante, seja ele o vaqueiro-herói- a iniciativa de definir-se com relação ao grupo. Outras variantes reforçam essa busca de contato do boi em uma outra seqüência: o marruá vem ao encontro dos homens no momento que antecede sua morte. É o caso do Boi Misterioso que reaparece no pátio da fazenda no dia da festa de São João. Só depois disso os vaqueiros conseguem rastrear o boi e pegá-lo. O mesmo acontece com o Bumba-meu-boi. Pressentindo que vai morrer o boi some, pra depois voltar. Neste sentido não seria exagero dizer que o boi se dá em sacrifício, ou seja, ele não se nega em relação com os homens. 
que garantiu espaço na memória coletiva. E, no desespero de sua condição marginal, tenta mostrar que nunca esteve tão longe dos homens assim. Revela-se consciente e orgulhoso de sua fama ${ }^{49}$ e sabe que exatamente por causa dessa fama foi que a comunidade estabeleceu com ele um elo pessoal, afetivo. Enquanto fala o boi se transforma para dramatizar o momento em que o "ser-individulaizado" dá-se ao universo das relações. O mesmo se passa com a comunidade que repete as palavras do boi encantado do romance. O boi que foi perseguido e morto, será chorado. Dele se sentirá saudades.

Boi bonito como este

No sertão não nascerá.

Eu chamava ele vinha:

O-lê, o-lê, o-lá ...50

Vemos portanto, que nessas variantes a comunidade não perde de vista o olhar afetivo, íntimo com que os vaqueiros olham para seus animais. $O$ mesmo boi que ousa desafiar os homens tenta recuperar no decorrer da narrativa a cumplicidade de seus perseguidores. Em fuga, ele é bicho obedecendo ao seu instino, porém sua natureza animal é substituída por uma outra, social. Simbolicamente esse boi mítico ilustra em sua versatilidade a unicidade da comunidade de vaqueiros. Depois de viver plenamente sua individualidade - justamente depois- ele se retira do jogo negando-se como particularidade. Como o vaqueiro na vida "real", o boi encarna em si a mesma ambivalência implícita na identidade coletiva.

Para que essa ambivalência se configure, a gente que produz o romance invoca ao boi toda a sorte de qualidades até que se chega a uma antinomia de sua figura: ele reúne em si sentidos divergentes e até mesmo contrários. É tanto animal quanto humano; é mal no discurso dos vaqueiros derrotados e vítima no discurso próprio; vive isolado, mas sabe da necessidade das relações para sobreviver. Criado a céu aberto é perigoso e selvagem -como tudo que encontra no sertão um abrigo. É contaminado de "sobrenatureza", por isso isolado, aleijado e perigoso. Mas é também doméstico; foi ferrado, castrado, tem nome. Perto dos homens, fala com eles. Reconhece "seu" patrão e "seu" vaqueiro. Além de tudo, é íntimo da comunidade que conhece de cór sua história ${ }^{51}$.

49 "Minha fama era tão grande/ que enchia todo o sertão" (O Rabicho da Geralda).

50 "O boi Surubim".

${ }^{51}$ Alencar (1960: 963) fala desse caráter doméstico/selvagem do boi criado solto. "Livre, tendo para esconder-se brenhas impenetráveis e o deserto onde refugiar-se, esse gado almargio, se não era de todo selvagem, também se não podia chamar doméstico". Calavia (1997: 162) esclarece que a ambivalênia doméstico/selvagem parece fazer toda 
Tal "dualismo" é revelador: na verdade, o boi seria o duplo do vaqueiro, o homem que transita entre dois códigos de conduta complementares: um para a maior parte de sua rotina, outro para o momento de enfrentamento do boi mais famoso do sertão. $O$ animal repete a ambigüidade do sujeito, aquele que ora parece estar "dentro", ora "fora" do mundo de relações. Aquele bicho toma para si todos os desejos ousados do "eu" e, ao mesmo tempo, todos os valores capitais da comunidade de vaqueiros, o "nós". Uma ambivalência que se lhe revela naquele local semi-desconhecido que é o sertão. Naquele espaço liminar, marcado pela capacidade de operar a inversão de polaridades, os protagonistas transfiguram-se, mudam de conduta ${ }^{52}$. Ali eles estão ora em grupo, ora sozinhos. O vaqueiro que trabalha para suas relações, poderá ser só para si. Um boi dócil, manso no meio do gado será selvagem e solitário. Animal agirá também como humano. Vivendo num espaço de interseção (espaço ideal para mudanças de posição), o boi tem a chance de se redimir.

A partir do momento que o boi experimenta toda a delícia do exercício de sua autonomia, ele não deixa de reconhecer o outro lado: toda a desordem, todo o desassossego, toda a insegurança e imcompreensão que seu isolamento implica. Não deve, portanto, surpreender-nos o fato desse boi falar, tentar salvar-se por meio de um discurso marcado pela pessoalidade. Isso prova que o sertão está no mundo e que quem lá vive não está tão isolado assim. Nas variantes autobiográficas o boi apadrinhado será, portanto, a imagem-símbolo53: ele é tanto o ser que dispersa a comunidade quanto o ser em torno do qual a mesma se une. Em sua figura é permitida a visualização de extremos e do processo de relativização destes. A criação desse ser único em sua alteridade questiona a idéia-força da relação pessoal como único recurso para

a diferença na simbólica desse animal. E completa: "Es difícil separar en cuanto al toro condiciones técnicas y simbólicas; o saber en que medida determinados intereses simbólicos han influido en relación práctica entre hombre y naturaleza, en la ganadería [...]. No parece arriesgado suponer que el toro llega a convertirse en símbolo privilegiado allá donde la crianza de ganado grande se da en áreas alejadas del núcleo habitado y su cinturón agrícola. Allí, su ambivalencia de animal salvaje y doméstico tiene cabida e interés. Las dehesas ocupan extensos terrenos que separan unos municipios de otros. El toro habita un lugar donde su ferocidad no causa problemas; de hecho, esa misma ferocidad es inducida [...]".

52 Como o deserto ou a floresta, o espaço liminar é o espaço selvagem por natureza; lugar dos foragidos, dos criminosos, dos espíritos, das forças demoníacas, mas também, e justamente por isso, o espaço onde se busca redenção, purificação: o espaço do ato heróico.

53 "Desde el mismo momento en que una 'cosa' (objetividad) entra en relación con el hombre, queda revestida de un sentido figurado, convirtiéndose en un símbolo" (Garagalza 1990: 57). 
sobreviver no meio social ao mesmo tempo que reivindica espaço para a individualidade dos sujeitos. Parafraseando Durand (1993; Garagalza 1990: 53), poderíamos dizer que o boi, em sua função simbólica, torna visível a dialética inerente à comunidade de vaqueiros.

A irrupção da consciência de si é que desencadeia o desejo de reconhecimento, de prestígio do vaqueiro. Este desejo acaba por chocar-se com a outra consciência, aquela que determina o compromisso com o grupo. Por isso a luta com o boi é de morte. Morto o boi conclui-se o processo de mediação. O desejo de auto-afirmação e o desejo de ser em grupo se encontram ao final co-implicados em um sistema de equilibrio dinâmico. Morto, o boi é o espectro de uma comunidade, que se confessa e se reconhece como relacional. Sua carne é repartida e ele passa a ser para todos novamente. Mas se "do boi nada se perde" como diz o povo, então entende-se porque não morre a idéia de autonomia que a lembrança do marruá evoca. Essa sua essência também será objeto de comunhão. Depois de morto, a imagem autônoma do boi famanaz continua a insistir na memória da comunidade. Ele despertará saudades. E a falta que ele faz é grande, a tomar pelo exagero quanto às dimensões das partes do boi descritas nos romances e quanto aos benefícios que cada uma delas propicia à comunidade. Uma falta que só faz aumentar no decorrer dos longos anos de perseguição que o boi sofre em todas as variantes. Cada perseguição enriquece sua história e as relações da comunidade com seu boi.

Portanto, se o desejo de participação é o verdadeiro algoz do boi encantado, ele mesmo é que permite o reconhecimento daquele ser singular, a permanência e a manutenção de sua individualidade no meio da coletividade. Sem adesão só haveria perseguição. O que significaria a inadaptação absoluta. É exatamente porque a fala do boi (essa forma de participação) o reintegra, que ela põe em evidência o caráter violento, a condição irreconciliável da luta onde se opõem ânsia de afirmação individual e desejo de reconhecimento do grupo. É na comunicação que os extremos são relativizados em sua contraposição. Seja na fala do boi, seja na narração emocionada do vaqueiro depois do trabalho, é o discurso do "ser-individualizado" que desmente o fato de que ser-para-o-grupo exclui o ser-para-si. É falando que o "outro" se apresenta para a relação. É o ato comunicacional que minimiza as contraposições solidão/relação, indivíduo/grupo, sertão/fazenda, homem/animal, doméstico/selvagem que o par boi/vaqueiro reproduz durante toda a narrativa.

Um equacionar extremos que o discurso do boi inicia e que, nas variantes autobiográficas, se conclui com sua morte. Íntegro, o boi continuaria a desenvolver uma imagem e a constituir uma identidade distintas daquelas que parecem controlar esses romances. Sua morte paralisa esse processo em vez 
de identidade, teremos identificação da comunidade com o boi ${ }^{54}$. Ele será tomado como exemplo: isolado, ele não tem como proteger-se; repartido para o grupo, nunca será esquecido. Através do boi é que a comunidade de vaqueiros elimina a descontinuidade das posições ocupadas por seus membros ${ }^{55}$. O equilibrio é restaurado recolocando cada coisa em seu lugar: há o tempo de estar só (mesmo que a presença do grupo seja velada) e há o tempo de estar junto (mesmo que o grupo mire-se no espelho da fama de um só).

A mensagem do romance, cujo emissor e receptor é o vaqueiro, será assim inequívoca. No fim, só permanece o que pode ser partilhado, o que pode ser comunicado, o que pode retornar para a coletividade. Do boi permanecerão os ossos, o couro, os chifres e, inevitavelmente, a fama. Permanências que denunciam antecipadamente o fracasso de uma tentativa de exclusão definitiva do "outro". No testamento das variantes autobiográficas, as partes do boi se encarregarão de transformá-lo, devolvendo a comunidade à rotina do sistema de relações pessoais ${ }^{56}$. Distribuídas aos membros da comunidade, as partes do animal criam novas e reforçam velhas relações. Do vaqueiro ao cadete, do povo à elite, das mulheres aos homens, dos jovens aos velhos, todos são envolvidos numa aliança, da qual cada parte do boi passa a ser um símbolo.

A imagem do boi encantado portanto traz à tona "a verdade da comunidade", revelando-lhe uma espécie dessemelhança em si. Se a morte dele é a vingança que volta sobre aquele que se isolou do grupo, a partilha definida por ele em testamento é sua reintegração. A morte dispersa a figura do boi apadrinhado, enquanto o testamento ou o banquete permitem o reaproveitamento das partes em um processo de recuperação-incorporação do "ser-individualizado". Como elemento articulador dos segmentos sociais, suas partes dadas em testamento permitirão a manutenção da autonomia do "nóscoletivo" em harmonia com a excepcionalidade do "eu-individual". O boi encantado será para sempre um espectro consolidado no seio do corpo social; um espectro que fala, comunica sua autonomia. Seu "eu" continuará a viver nos "seus" vaqueiros e neles continuará a agir. Esse é o segredo do Boi Misterioso!

${ }^{54}$ Aqui estamos em dívida com Viveiros de Castro (1986).

55 "[...] el toro marca por fuera los límites del mundo humano" (Calavia 1997: 151).

${ }^{56}$ Pilar García de Diego (1953: 602) já nos falou das características dos animais que fizeram testamentos pelo mundo afora. Esses animais são personagens centrais dessas narrativas que revelam sua [do animal] integridade moral e humana. E mais - diz a autora- sua "perfección humana puede explicarse en algunos casos, por ser estos animales hombres metamorfoseados, en castigo de alguna falta cometida [...]". A falta cometida por nosso boi já sabemos qual foi. 


\section{O VAQUEIRO-HERÓI}

Por onde passa o boi, passa o vaqueiro e seu cavalo.

(Provérbio Popular)

Mas não nos esqueçamos dos romances narrados em terceira pessoa, nas quais o boi só fala antes de morrer. Como em todas as variantes, nestas outras o boi perseguido será também o pivô do isolamento dos membros do grupo. Um boi que só fala antes de morrer e que, portanto, só então começa a trabalhar pela união. Esclarecemos. No momento da perseguição ao boi famoso (aquela realidade que o romance registra simbolicamente) cada vaqueiro vive apenas o presente e o futuro. O compromisso com o passado -isto é, com suas relações- definha. Sua orientação é para o presente da aventura e para o futuro das conseqüências de seu feito. Quando o boi fala porém, tudo se inverte. No seu discurso para tentar evitar o inevitável, o boi, falando de seu passado, como que arranca a comunidade de vaqueiros daquela amnésia e a resgata para o tempo de suas relações, o tempo de compromisso entre companheiros.

Para não morrer, o boi mostra a outra face de sua persona. Neste momento é como se o vaqueiro-herói estivesse diante de um espelho que reflete uma sua imagem atual invertida ${ }^{57}$. No cara-a-cara vaqueiro/boi, um será sempre a face oculta do outro. O boi fala e apresenta-se como aquele que está em busca de relações, de reconhecimento. Mas sua fala não surte o efeito esperado $^{58}$. O vaqueiro mata o boi, apesar do apelo do animal, e apresentase como aquele que questiona o valor da relação como única forma de definição dos sujeitos. A partir daqui o vaqueiro-herói troca de posição com o boi; agirá por si, será ele —não mais o boi- o merecedor da admiração de todos.

No caso das variantes em que um determinado vaqueiro assume as rédeas da narrativa, o herói terá que matar o boi se quiser ser reconhecido, se quiser afirmar sua individualidade 59 . Se não cumpre seu "destino" de herói, o

57 "La reduplicación no es antítesis, es dualitud más que dualidad; como dicen los antropólogos, se trata aquí de un dualismo concéntrico en el que las dos partes, en el que los dos términos se enfrentan [...]" (Durand 1993: 182).

${ }^{58}$ A perda de efeito do discurso como desencadeador de relações pode ser vista num outro detalhe das variantes em terceira pessoa: nestas, depois de morto, o boi não será chorado.

59 "O processo fundamental de afirmação de uma individualidade se manifesta através do 'desejo de matar' as individualidades que entram em conflito com a sua. A afirmação absoluta de uma individualidade provoca a destruição da outra" (Morin 1997: 68). 
vaqueiro não tem como recuperar-se para o grupo; o grupo não teria como torná-lo "celebridade". Nas variantes em terceira pessoa, o vaqueiro-herói (não mais o boi) será o ator a encenar o "tipo geral" no qual todos se reconhecem. Em sua figura unir-se-ão o caso particular e o geral. Habilidade que se perde de vista ao boi encantado.

Nas variantes em que o vaqueiro-herói assume e leva a cabo o papel de "ser individualizado", a missão de controlar a força de dispersão que o boi encarna sairá das mãos do grupo e passará às mãos de um membro do grupo. Não mais um grupo de vaqueiros ou de cães ferozes vencerão o boi, mas sim um só vaqueiro. Uma tarefa que só poderia caber a alguém especial. Como o boi encantado das variantes autobiográficas, o vaqueiro-herói é alguém que, vivendo em um mundo, é capaz de se comunicar com o "ser do outro mundo". O que o romance parece querer esclarecer é que, só em função desse boi-sozinho o vaqueiro se individualizará também. Só por causa daquele bicho, o homem será mágico e assumirá o controle sobre o sertão ${ }^{60}$.

Nas variantes autobiográficas, o boi independente, mas que sabe da importância das relações para sobreviver, é o alvo da identificação dos membros da comunidade. Ele é o objeto de comunhão. É com ele que a comunidade se identifica. Portanto, às partes do boi cabe a função de mediador dos extremos, como vimos. Mas, a partir do momento que um membro da comunidade é feito herói, a mesma função se transfere para este personagem. Teremos portanto duas individualidades no romance, sendo que ao final uma mata a outra para se afirmar. Boi morto, a fama deste como que contamina o vaqueiro e faz do segundo vetor de identificação. A função de mediador vai junto. Como o boi das variantes autobiográficas, o vaqueiro-herói é tanto aquele que se isola do grupo quanto aquele do qual depende a relativização de seu isolamento por meio da narração de sua façanha. Por isso, o testamento do boi sofre uma disfunção nessas variantes. O processo de incorporação do "outro", agora vaqueiro-herói, se dará de outra maneira. Os extremos serão relativizados em uma outra espécie de comunhão: a socialização da glória do herói.

Por isso o momento do combate é decisivo para que o equilíbrio seja levado a efeito nas variantes em que aparece o vaqueiro-herói. Morto o boi caberá ao herói voltar para o grupo e apresentar-se para a prova de reconhecimento (em outras palavras, para as relações). Ao mesmo tempo dispersor e mediador, o vaqueiro-herói é tão ambivalente quanto o boi das variantes

\footnotetext{
${ }^{60}$ DaMatta (1993: 104) ensina que a individualização do pescador ou caçador (no nosso caso do vaqueiro) se dá quando eles adentram o mato ou o rio (no nosso caso, o sertão). Nestes "entre domínios" o ator "está só e despersonalizado e por isso aberto às "experiências perigosas e encantadas, em que este mundo pode se confundir com o outro mundo".
} 
autobiográficas. Sua alteridade se destaca em vários detalhes, colocando-o em condições de igualdade com o boi que enfrentará. Ele também é humano e animal (ele se veste como o boi, traz cobras nos bolsos do gibão, está em simbiose com seu cavalo). Se o boi é obstinado, por obstinação é que o vaqueiro consegue vencê-lo. Se o boi é mandigueiro, ele só poderá ser vencido por um vaqueiro-feiticeiro.

Por outro lado, se o boi é castrado, destituído de sua sexualidade, o vaqueiro está pronto para se casar. Se o boi anda só, o vaqueiro conta com seu cavalo, seus cães. Se o boi foge para o sertão, o vaqueiro-herói age com autorização do fazendeiro. O romance destaca tanto as semelhanças quanto as oposições críticas entre os protagonistas. Novamente o jogo especular da comunidade que evita tanto a contradição absoluta quanto a identidade entre animal e homem. Uma estratégia interessante. Parafraseando Viveiros de Castro, diríamos que, no caso, a comunidade de vaqueiros passa a ditar as regras desse jogo especular boi/vaqueiro numa visão bifocal que é redirecionada no decorrer da narrativa em benefício da inclusão do "ser individualizado".

Isolado, o vaqueiro-herói será estrangeiro. Só ao vaqueiro vindo de longe é admitido vencer sozinho o boi orgulho de todos da região. Parece que o membro da comunidade nunca poderia (ou deveria) fazê-lo ${ }^{61}$. Como se ela só devesse matar o boi pelas mãos de muitos, sob a mira de muitos rifles ou nos dentes de cães ferozes. Porém, se para a comunidade de vaqueiros a solidariedade é um valor irrenunciável, o isolamento desse herói nunca será absoluto. "Pessoa", atado moralmente a suas relações, o vaqueiro-herói não poderá agir por si só, mesmo sendo "estrangeiro". Sua individualidade ainda é muito grande para ele. Por isso, é preciso que sejam inventadas formas de salvaguardar-lhe alguma espécie de relação no momento do ato heróico. Como isso é feito? Em nossas variantes nunca se realçam as habilidades profissionais do vaqueiro sem que as mesmas sejam colocadas em relação de causalidade mecânica com seu cavalo e/ou sua força mágica. Sendo assim, para ir à caça do boi terrível, o vaqueiro será transformado em "centauro" ${ }^{\text {"62 }} \mathrm{e} / \mathrm{ou}$ em feiticeiro.

\footnotetext{
${ }^{61}$ No caso, parece que nunca poderiam fazê-lo. Para lidar com Calundu "não era qualquer vaqueiro chegado de fora, não" — diz com orgulho o vaqueiro que respeita (e muita vezes protege através de sua mágica) o seu boi. Calundu (Rosa 1983: 26) desafia vaqueiro de fora, ou melhor, ele se relaciona melhor com os vaqueiros da região, os de "sua" comunidade. O boi reconhece os "seus" como os homens acumulam experiência sobre o modo de relacionar-se com "seus" bois.

${ }^{62}$ A metáfora é de Euclides da Cunha (1933: 116). "[...] onde passa o boi, passa o vaqueiro com seu cavalo. Colado ao dorso deste, graças à pressão dos jarretes firmes, realiza a criação de um centauro bronco."
} 
Analisemos primeiramente o "centauro". Ao vaqueiro-herói será conferido um auxiliar: um cavalo maravilhoso. O cavaleiro será definido em relação a sua montaria, numa simbiose que revela o caráter relacional daquele que se individualiza. Mais que da habilidade própria, pegar o barbatão depende da habilidade do cavalo do vaqueiro. Além do mais, dos vaqueiros, apenas seus cavalos. É o que o poeta Suassuna (1974: 109-110) deixa claro quando nos narra "A morte do touro Mão de Pau".

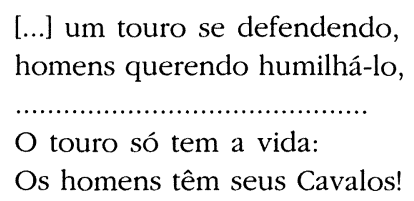

A simbiose é tão perfeita, que várias vezes vaqueiro e cavalo se fundem no discurso do romance. Ao mesmo tempo que se fala do vaqueiro habilidoso, se fala do seu cavalo maravilhoso. Perguntado se poderia quebrar o feitiço do boi, o cavaleiro-herói responderia que nunca encontrou "boi que deitasse poeira a seu cavalo" (Alencar 1959: 1143), ou que "vaqueiro a cavalo não corre com medo de boi" (Rosa 1983: 37). Depende da montaria a vitória sobre o marruá encantado porque, na verdade, quem vence o boi é o cavalo. Por isso, no imaginário sertanejo:

o homem nunca pode ser mais forte que seu cavalo. Não que o cavalo não seja domesticado. Mas, numa guerra ou batalha o cavalo mostra a força que ele tem sobre o homem. Então o homem tem que conversar e criar o cavalo para que eles se tornem amigos, pois o homem tem sempre um cavalo [...], o homem como que assume o seu corpo $[\ldots]^{63}$.

O recurso que a comunidade tradicional usa para evitar o isolamento completo do herói é surpreendente. Se só um determinado cavalo é capaz de vencer o boi batizado, somente o vaqueiro, dono deste cavalo, poderá ser reconhecido como herói. Essa exclusividade é própria do pensamento que se guia pela noção de coletividade e concede, com reservas, espaço ao "indivíduo". Uma exclusividade que harmoniza — hierarquizando- as relações do grupo. Se qualquer cavalo pudesse vencer o boi, significaria que qualquer vaqueiro poderia ser herói. Bastariam para isso suas habilidades individuais. A onipotência do fado estaria quebrada diante dos "indivíduos", aqueles que são iguais e que portanto possuem chances iguais. A competição seria institucionalizada comprometendo cada vez mais a solidariedade entre os sujeitos. Apesar de a comunidade criar tal ilusão num primeiro momento, as oportu-

\footnotetext{
${ }^{63}$ As palavras são do pintor Octávio Ignácio citado por Silveira (1989: 99).
} 
nidades não são as mesmas para todos os vaqueiros do romance, simplesmente porque seus cavalos não são iguais.

Da realidade de vida do vaqueiro, o romance toma de empréstimo um outro artifício que garante ao vaqueiro valente, dono de um cavalo maravilhoso, a condição de fadado a herói. Para vencer o boi feiticeiro não bastaria somente ser dono de tal cavalo; seria preciso ser capaz de quebrar o feitiço do mandigueiro. A "sobrenatureza", constante no cotidiano da comunidade de vaqueiros, vem para dentro do romance configurando-se como outro tipo de relação possível para evitar o isolamento definitivo do herói frente ao boi também feiticeiro.

Benício (1997: 43-75) registra em suas crônicas históricas do costume sertanejo um belo exemplo de vaqueiro-feiticeiro. Em 1887, foi marcado o dia da péga do boi Cornetd ${ }^{64}$, apadrinhado pelo vaqueiro Manuel Quadrado, respeitadíssimo por todos na região de Laje Grande, sertão baiano. Raimundinho Doutor $^{65}$ é desafiado a pegar o boi terror da região. Empolgado, o rapaz canta glórias dizendo que sabia orações mais fortes que as de qualquer vaqueiro daquelas bandas. Quebrar feitiço de boi não seria problema para ele. Mas faltava algo essencial ao vaqueiro baiano: um bom cavalo. Vendo os ares pretenciosos do moço, o próprio Manuel Quadrado diz: "Se é por isto eu posso ceder-lhe o meu Mata-Garrote". No dia da péga, Raimundinho sai no encalço do boi e não faz feio, até que o bicho lhe prega uma peça e ele cai do cavalo (literalmente) em cima de uma moita de espinhos. Ali Manuel Quadrado vai encontrá-lo, depois de ver que Corneta estava preso em seu curral. Sucedera o que o traquejado vaqueiro havia previsto. "O que vocês não fizeram, fez o cavalo que lhe dei para montar, seu Raimundinho". O cavalo havia capturado o boi Corneta. "Vamos agora pegá-lo, laçá-lo [...] e será o senhor mesmo que o há de levar na frente, até dentro da fazenda do Marinho. Ninguém saberá do que houve". Cavalgando Mata-Garrote, Raimundinho "entrou glorioso no pátio da fazenda do Marinho, entre ovações e gestos de entusiasmo". Pela generosidade e discrição do cavaleiro Manuel Quadrado, o vaqueiro Doutor tornou-se para sempre um leal amigo do "vaqueiro feiticeiro".

\footnotetext{
${ }^{64}$ Corneta é o nome dado ao boi que possui só um chifre. Cascudo (citado por Bastos 1979: 28) diz que segundo as palavras dos próprios vaqueiros, "o boi corneta é de mau gênio, barulhento e brigador. Ele tenta sublimar pela violência a falta da cornamenta. O defeito físico evidente justifica o desajustamento individual na convivência". Neste caso, discordamos do grande folclorista. Não seria o defeito físico que justificaria o isolamento do boi, mas sim o contrário. O boi não é mágico porque é corneta, mas, sim, é corneta porque é mágico. Os bois isolados nos romances são quase sempre "aleijados". Esta é uma forma de se destacar aquele contaminado de "sacralidade", ou se preferem, de sobrenatureza.

${ }^{65}$ Chamado pela alcunha Doutor porque sabia ler e escrever.
} 
Podemos identificar aqui toda a manobra para evitar que o herói se torne indivíduo auto-contido. Que seja reconhecido como auto-suficiente o cavalo, mas não o membro do grupo. E mais: se Manuel Quadrado é respeitado em toda a região, não o é apenas por causa do seu cavalo, não o é apenas porque batiza boi; mas também (e não seria principalmente?) porque segue à risca o código do sertão. Ele não é o vaqueiro mais famoso da região porque é dono de Mata-Garrote; mas sim, Mata-Garrote lhe pertence porque ele é o vaqueiro digno de ser herói. Ele é discreto, fiel, leal, honrado. Não conta vantagens (como faz o Doutor). Não pisa no companheiro derrotado para aumentar sua fama (sabe que isso seria sua perdição). Ao contrário, omite os fatos para ajudar o outro ganhando assim um amigo fiel. Importante para ele são as relações. Não seria exagero dizer que disso depende sua vida ali pelas bandas do sertão.

O vaqueiro será reconhecido por causa de seu cavalo e de sua "mágica". Estas são as marcas do herói. A esse homem, cuja solidão é pura miragem, suas relações (o cavalo e as orações aprendidas com o pai que também era vaqueiro-feiticeiro) garantem a vitória. Nos vemos, pois, diante de uma dominante do pensamento brasileiro segundo DaMatta (1987: 64):

O ponto crítico da identidade social no Brasil é, sem dúvida, o isolamento (e a individualização), quando não há nenhuma possibilidade de definir socialmente alguém por meio de uma relação com alguma coisa (seja pessoa, instituição ou até mesmo um objeto ou atividade).

Percebe-se que a autonomia do vaqueiro-herói ou do boi encantado com relação ao grupo é bem menos decisiva do que poderíamos imaginar numa primeira leitura dos romances. O comportamento de ambos deve corresponder ao princípio ordenador das relações sociais. Um princípio que objetiva o equilíbrio na co-existência de individualidades num sistema que se rege pelo império das relações. Em obediência a esse princípio é que na maioria das variantes que analisamos o boi fala quando vê que o vaqueiro está para vencêlo. Ele discute abertamente seu dilema e se defende; prova que é valoroso o suficiente para continuar a viver. O momento do combate também obedece àquele mesmo princípio ordenador. Daí a preocupação explícita em resguardar o princípio de igualdade de condições dos desafiantes, exatamente como prescreve o código de honra que rege o duelo de cavaleiros ${ }^{66}$. O boi

${ }^{66}$ Os mais importantes folcloristas brasileiros já falaram da paixão do nordestino pelos livros de cavalaria. Em uma sociedade onde valores morais são a espinha dorsal do sistema, não é de se espantar a identificação dos homens simples do sertão com o rei Arthur ou com Roldão. "En la época a que me refiero -diz Caro Baroja (1964: 425) ao falar do medievo-, el ideal de la sociedad para la que el 'más valer' era lo fundamental en la vida, se halla expresado literariamente en los libros de caballería". 
apadrinhado terá o sertão aberto para fugir ${ }^{67}$ e a proteção mágica do seu padrinho. O vaqueiro estará em grupo ou terá um guia, ou suas mandingas, seu cavalo. Ambos devem demonstrar bravura, coragem, lealdade e "firmeza". A luta é irreconciliável, porém deve ser limpa ${ }^{68}$.

A igualdade de condições como essencial ao duelo, revela que este é o ponto de interpenetração das duas faces do sujeito social que os protagonistas dramatizam no romance. No combate, o vaqueiro entra em ressonância com o boi para entender como momentos de "individulização" são fatos dentro de um sistema de solidariedades. Finda a luta, o vaqueiro se transfigura junto com sua vítima no momento do diálogo seguido do banquete, quando divide os louros de sua glória. Vaqueiro-herói e boi cumprem seu destino comum: voltam. E nos casos em que o vaqueiro aparece como herói, ele será aquele que cuida dessa "ritualização" da volta.

No grupo de variantes separadas para a análise nesse trabalho, "voltar" implica matar o boi feiticeiro. Diante da súplica do barbatão por mais uma chance, o vaqueiro responde:

\author{
Ainda que eu quisesse \\ Não posso fazer-te o gosto, \\ Pois sabes que eu moro longe \\ E só tomara te ver morto (Pereira da Costa 1908: 412).
}

Ainda que eu quisesse... O vaqueiro não se contradiz ${ }^{69}$. Ele deve honrar sua palavra. Ele é forasteiro e tem que matar o boi se quiser ser reconhecido como membro daquela comunidade. Sua glória, a ser dividida, o boi a ser dado

${ }^{67} \mathrm{Um}$ dos personagens de Alencar, no episódio do banquete no dia da pega do boi Dourado, diz que há diferença entre "matança" para comer e vaquejada. Esta pressupõe igualdade de condições entre homem e boi: o primeiro tem direito de tentar pegá-lo; o segundo tem o dereito de fugir e a ele é concedido espaço pra isso.

${ }^{68}$ Perseguir boi cercado ou vencê-lo através do uso de armas não é o feito mais honroso. O vaqueiro deve provar sua superioridade de mãos vazias, "pegar o boi pelo chifre" como diz o ditado popular. A luta leal pressupõe a igualdade de condições que pode ser vista em outros romances como "Lanzarote e el ciervo de piés blancos" e na colindã romena "Der Sieg über die Löwen" (Taloş 1988: 96-138). Regras que heróis como Hércules, Sansão, Cid e Rolland cumpriram à risca.

69 Novamente o romance traduzindo a experiência do real. No dia-a-dia, o vaqueiro é o responsável tanto pela unidade de seus animais quanto pela unidade de seu grupo. O gado só existe no sertão aberto, porque o vaqueiro está lá para ele. Com o grupo de trabalho não é diferente. Levar o boi de volta, significa voltar também. A sociedade ainda não havia encontrado um jeito de trazer de volta o vaqueiro que encarnou a natureza do boi sem que este precisasse morrer. Como disse Alencar (1960: 964), ainda "era essencial acabar com o marruá "para que não atraísse o outro chamado manso, e o desencaminhasse". 
em banquete de casamento são seu bilhete de entrada. A iniciativa de apresentar-se para as relações com o grupo deve ser dele. Como o boi das variantes autobiográficas, ele é o de fora, ele é que está isolado. Como o boi toma a iniciativa de falar, o vaqueiro-herói deve fazer o mesmo: narrar seu feito.

Acontece que esse herói não tem como se livrar de sua condição paradoxal, já que a lembrança do boi jamais o deixa; vai com ele para a comunidade. Sempre que se olhar para o vaqueiro estrangeiro, será visto o boi famoso por ter vencido tantos sozinho. Conseqüencia do equilíbrio, este que se faz tendo em vista no mínimo dois. Através do vaqueiro-forasteiro se instala "o outro", com todas as honras, no sistema social. Devido ao seu contato direto com o boi apadrinhado, o vaqueiro se torna um sujeito importante naquele meio, trava relações. Deve ser tratado com "o devido respeito" e "a devida consideração". Deferência que nunca the seria negada, porque o que maravilhava a esses homens valentes e habituados aos perigos de sua profissão não era a coragem do homem que enfrentava a morte, mas a submissão do boi mocambeiro.

\section{CONCLUSÃO}

Na boiada já fui boi, boiadeiro já fui rei.

(Geraldo Vandré)

Se a noção de "pessoa" de uma comunidade "não só deve ser procurada, mas construída pela análise" (Viveiros de Castro 1986: 125), vemos que, no caso das variantes analisadas, ora o vaqueiro-herói ora o boi encantado do romance são os objetos de procura e construção. Daí o isolamento desses personagens aparecer cercado por todos os lados no romance. Se a função da "pessoa" é ser múltipla, o vaqueiro que age independentemente do grupo, depende, em contrapartida, de seu cavalo, de sua mágica. Já o boi, que vive só pra si, livre no sertão, fala do relacionamento dos homens para com ele e revela que sempre esteve, de alguma forma, em contato com eles. Por encarregarem-se da materialização da noção de "pessoa" da comunidade nas gestas é que a natureza de boi encantado e vaqueiro-herói se contaminam. Isso sem que as figuras percam a identidade própria de cada uma. Afinal, o que se pretende não é o "mesmo", mas a coexistência harmônica dos "diversos". "Identificação" em vez de "identidade". Se a identidade fosse o ideal perseguido, o boi não morreria depois de contar sua história e definir-se com relação à comunidade de vaqueiros. A identidade entre boi e vaqueiro presentearia ao primeiro a vida e concederia ao segundo mais espaço para sua individualidade. 
A "maneira de ser coletiva"" se construirá a partir das qualidades específicas do vaqueiro-herói e do boi sem exclusão de nenhuma delas, mesmo que sejam contraditórias entre si. Boi e vaqueiro se unem em suas continuidades e descontinuidades porque a mesma consciência que dirige o romance, ao mesmo tempo que nega, reconhece um espaço para a afirmação individual dos membros da comunidade. A individualidade é negada como definitiva, mas reconhecida como fato. Assim, o que se faz é postular uma identidade mais inclusiva da comunidade de vaqueiros, no sentido de que esta se reconhece na pluralidade de "destinos individuais"71. Que outra justificativa poderíamos apresentar à insistência das variantes em evocar detalhadamente, um a um, os vaqueiros derrubados pelo boi? De fato, uma atitude que parece inofensiva, mas que, na verdade, reforça a familiaridade dos companheiros de trabalho entre si e destes (enquanto grupo) com o boi encantado. Nascida do experimentar coletivo dos sentidos, tal familiaridade gera uma segurança com relação à recepção do "outro". Através daquela já citada empatia (Einfüblung) movediça que a narração vicária da gesta estabelece faz-se uma projeção que é essencial ao processo de construção identitária da comunidade: boi e vaqueiro interagem um com o outro, um sobre o outro até que a os extremos se matizem e o equilibrio seja restaurado e a noção de "pessoa" da comunidade se (con)firme.

Sendo assim, a perseguição do boi não é jamais exercida na base de uma reciprocidade simples, vaqueiro/boi como pode parecer à primeira vista. A perseguição por atacado, a evocação global de toda a gesta caracterizando sempre a comunidade envolvida, tudo isso revela o modo usual de vida do grupo e manifesta a força coletiva amparando o herói do romance e/ou controlando o boi. E a simplicidade do desejo de pegar o barbatão passa a servir de significante a operações bem mais complexas. A perseguição do boi deixa marcas na memória da comunidade co-autora, atriz e espectadora (re)cobrando as relações desta com aquele que afirmou-se em sua individualidade. Por isso, a morte do boi provoca tanta tristeza. Seu exemplo está, de qualquer forma, gravado na memória coletiva, depois do jogo de identificações e substituições que é elaborado dentro das variantes, onde o lugar daquele que se isola do grupo circula incessantemente criando uma figura contínua, onde as posições de sujeito individualizado e sujeito relacional se fundem e se inter-exprimem, de modo que a aspiração dialética da comuni-

${ }^{70}$ A expressão é usada por Maffesoli (1996: 147). As maneiras de ser coletivas, são "ao mesmo tempo gerais quanto à intenção e particulares quanto à inscrição local, quanto à efetuação".

71 "En esta conincidentia oppositorum lo 'otro' no se reduce a lo 'mismo', pues la diferencia se sigue manteniendo en el seno de un pluralismo coherente" (Garagalza 1990: 39). 
dade se cumpra. Os personagens fundam sua identidade aceitando-se em simbiose com o outro. O desejo de afirmação individual em harmonia com o desejo de participação no grupo são realizados de forma alternativa, portanto total.

É esse pensamento dialético que faz com que cada personagem seja apresentado tanto como específico quanto como parte do todo que é o modo de ser coletivo. O objetivo é sim incorporar o outro em suas semelhanças sem apagar-lhe as diferenças (identificação), não fazer do outro um igual (identidade). É por isso que vaqueiro e boi englobam a natureza um do outro num processo de aproximação que podemos classificar como moral ${ }^{12}$. Eles se transfiguram sem renunciar a sua essência. Assim se confirma a opção coletiva por um tipo de pensamento mais inclusivo que aceita que opostos se coadunem, se misturem, se matizem. Conclui-se pois, que o pensamento que dirige a ação do romance não é em absoluto dualista. Os pólos boi/vaqueiro não são concebidos de outra forma que não interpenetrados; facetas de uma mesma "pessoa". Ao contrário do que o romance diz, não penso que seja o boi encantado que reconheça o vaqueiro-herói, mas sim o contrário. A comunidade, na pessoa do vaqueiro, persegue no romance uma porção de si mesma.

As variantes analisadas parecem mesmo querer demarcar o cruzamento dos limites "eu" e "nós". A partir do cruzamento ficaria estabelecido o ponto de co-relação, criar-se-ia o espaço de co-existência. Teremos, portanto, um barbatão extremamente audaz e independente, mas que se dará a repartir, sendo novamente para o grupo. $\mathrm{E}$ um herói que, na verdade, não pode ser "indivíduo", anônimo. Deve ser famoso, socializar sua glória, ascendendo como vaqueiro e levando junto toda sua categoria ${ }^{73}$. Vaqueiro-herói e boi encantado são, pois, figuras emblemáticas construídas pela e construtoras da participação coletiva. Os dois favorecem a agregação pela admiração que suscitam. Fundem a comunidade que em torno deles se encontra. Não é por outro motivo que eles são o orgulho de todos. Ambos tornam sensível tanto a separação implicada nas subjetividades diversas de que se compõe o grupo, quanto a unidade do mesmo grupo, a partir do momento que valem pelas

${ }^{72}$ A comunidade se junta em torno do poeta popular para repetir as palavras do boi. A proximidade moral entre este e o vaqueiro se repetiria nessa hora entre boi e comunidade, entre vaqueiro e comunidade, e confirmaria que as relaçoes são mais importantes que os indivíduos nelas envolvidos.

${ }^{73}$ Um paralelo interessante pode ser feito com os heróis criaturas das sociedades individualistas. Heróis como o Superman, Batman, Zorro são condenados ao anonimato. A "identidade" secreta, como o nome mesmo já diz, garante a esses heróis o lugar na sociedade em que todos "são" (ou deveriam ser) iguais. Ao contrário do herói "tradicional" que busca o reconhecimento, esses heróis procuram evitá-lo a todo custo. 
relações que estabelecem e favorecem. Através deles é que se atualiza a essência social, o que Maffesoli (1996: 147) chama de "dimensão afetual".

Para que seja mantido o equilibrio identitário do grupo (equilibrio que não pressupõe, veja bem, simetria), ou o boi fala durante toda a narrativa ou fala o vaqueiro-herói no fim, narrando sua aventura; ou fazem testamento do boi ou banquete de casamento; ou um grupo apanha o bicho ou a tarefa caberá a um vaqueiro vindo de outras paragens; Morto o marruá, o mundo das relações será sancionado através das partes do boi-Fama ou da construção da fama do vaqueiro-herói. Incorporado o "ser-individualizado" em sua essência, esta se mistura ao todo relativizando a condição de dissidente do primeiro. De um boi teremos muitos, cada parte promovendo novas relações e trabalhando agora para a unicidade do grupo. Ao comer da carne do boi, ao fazer uso de seus ossos, de seu couro, de seus olhos, cascos e cauda para produzir ferramentas, enfeites, utensílios domésticos e toda uma variedade de bens culturais, ao cantar as memórias daquele boi valoroso, a comunidade (re)elabora a sintaxe de uma "maneira de ser coletiva". Desta maneira como diria Viveiros de Castro (1986) - o boi famanaz, sua força, sua essência "mergulham na segurança identitária da sociedade" e assim, "mais que insiste, subsiste" nas atividades da comunidade, mesclando-se à estrutura de relações. As partes do boi reforçam a ausência daquele ser singular e colocam em curso o processo de subordinação deste à comunitas. O boi encantado fica preso ao "campo perceptivo-afetivo da comunidade, invertendo a imagem mental que o todo provocava"

O mesmo efeito provoca a construção da fama do vaqueiro que capturou o boi mandigueiro sozinho. Do vaqueiro único persistirá a glória, repartida, relativizada em seu caráter de conquista individual. Orgulho de todos os companheiros de profissão, a glória do cavaleiro será sociabilizada criando simpatias e respeito mútuos, ocupando lugar no discurso de todos, estabelecendo relações. Será repartida como foi o boi das variantes autobiográficas. Portanto, o boi ainda estará onde o vaqueiro estiver. Depois de ser definido por seu cavalo, o vaqueiro será definido pelo boi famanaz. Ele, que se casará com a filha do fazendeiro, carregará para sempre as vantajosas conseqüências de seu feito e resgatará sempre na memória daqueles que fazem parte do seu ciclo de relações a lembrança do boi que venceu sozinho. Afinal, ele não seria o que agora é se não fosse o boi feiticeiro. Poderíamos dizer que o vaqueiro é muito mais que Teseu. A simbiose não é outra que aquela que ocorre entre cavalo e cavaleiro: o centauro transforma-se em minotauro. De qualquer forma, ele não tem como negar sua natureza hỉbrida.

\footnotetext{
${ }^{74}$ (Viveiros de Castro 1986). O que não quer dizer que a imagem que o todo provocava esteja definitivamente apagada. Ela continua a viver na memória daqueles que choram o boi e cantam a glória do vaqueiro.
} 
Seja por metonímia (as partes pelo boi), seja por metáfora (o vaqueiroherói pelo boi), na verdade o que se aproveita do boi não é sua matéria, mas sim a relação. A fama (do marruá ou do cavaleiro) repartida cancela de fato a diferença que se deseja superar. Ela torna-se patrimônio de todos. O ser autocontido se transforma em um ser para as relações. Diríamos que o processo de isolamento se inverte: aquele que de início se isola individualizando-se será enfim "pessoalizado". Separar os componentes do boi é confirmar a impossibilidade de sua existência como ser isolado. "Tradicionalizar" a fama do vaqueiro-herói e do boi encantado é reconhecer a pertinência do desejo de se desenvolver uma fisonomia própria.

Agora podemos entender a peripécia da comunidade de vaqueiros para preservar sua identidade. Nas variantes, ela focaliza, não o marruá, mas sim o homem que persegue o boi encantado. A luta contra aquele animal arredio não era, nem poderia ser, em absoluto, a novidade. Pelo contrário! A cena se repetia diariamente. Se os vaqueiros mesmos já não haviam vencido um barbatão, conheciam ou de fama ou pessoalmente mais de um companheiro que se orgulhavam de semelhantes façanhas. De certo, o que queriam mesmo era, através da submissão do boi protegido de vaqueiro-feiticeiro, descobrir qual era o vaqueiro mais poderoso. O que se pretendia era tomar do padrinho - e não do boi- a fama e garantir o direito a uma biografia, um espaço na memória coletiva, o direito de ser reconhecido por suas habilidades individuais.

É por isso que, através do romance, o boi-Fama fica retido no tempo, controlado, capaz de voltar todas as vezes que se cantar o romance. A pressão que essa lembrança exerce é qualitativa e se distribui por todo o sistema social,

pois sempre, ao rebanho, espanta

que um touro do nosso Gado

às teias da Fama-negra

prefira o gume ao Fado (Suassuna 1964: 110, 111).

ANEXO I

O Boi- Espácio

(trecho da versão sergipana de Sílvio Romero)

No ano em que eu nasci, No outro que me criei, No outro que fui bezerro,
No outro que fui mamote, No outro que fui garrote, No outro que me caparam Andei perto da morte. 
Minha mãe era uma vaca, Vaquinha de opinião; Ela tinha o ubre grande Que arrastava pelo chão.

Enquanto fui barbatão Nunca entrei no curralão.

Foi-me tudo ao contrário E sempre fui perseguido; Já me conhecem o rasto, O Boi-Espácio está perdido. Não tem a culpa o Ferreira, Que não me pôde avistar, Foi o caboclo danado Que parte de mim foi dar. O seu Antonio Ferreira Tem três cavalos danados:

Três cavalo endiabrados! Mas eu não temo cavalo, Que se chama Deixa-fama, Também não temo o vaqueiro Que derrubei lá na lama. Me meteram no curral, Me trancaram de alçapão; E bati num canto e noutro, Não pude sair mais não! Adeus, fonte onde eu bebia, Adeus, pasto onde eu comia, Malhador onde eu malhava; Adeus, ribeira corrente, Adeus caraíba verde, Descanso de tanta gente!....
O couro do Boi-Espácio Deu cem pares de surrão, Pra carregar farinha Da praia de Maranhão.

O sebo do Boi Espácio Dele fizeram sabão Para se lavar a roupa Da gente lá do sertão. A língua do Boi-Espácio, Dela fizeram fritada; Comeu a cidade inteira, Não foi mentira nem nada.

Os cascos do Boi-Espácio, Deles fizeram canoa, Para se passar Marotos Do Brasil para Lisboa. Os chifres do Boi-Espácio, Deles fizeram colher Para temperar banquetes Das moças de Patamuté. Os olhos do Boi-Espácio, Deles fizeram botão Para pregar nas casacas Dos moços lá do sertão.

E da pá do Boi-Espácio, Dela se fez tamborete Para mandar de presente A nosso amigo Cadete. Do rabo do boi-Espácio, Dele fizeram bastão Para as velha de cima Andar com ele na mão.

Anexo II

O Boi-Espácio

(Trechos da variante pernambucana de Pereira da Costa)

Diz o dono da fazenda:

- De que fazenda vós sois?

- Eu moro na "Meladinha",

- Quantos dias de viagem?

- Hoje fazem 32 ,
Pela notícia que tive

E a fama de seu boi

- Me chamo Manoel Lira, Um criado do senhor. Para todos seus vaqueiros, Peço que venha ver, 
Peço que não me acuda Deixe matar ou morrer. Se morrer não morro só, Temos de morrer os dois, Que eu nunca temi a homem Como temerei a bois?

Diz o dono da fazenda - Se está determinado Ao boi sempre matá, Escolha dos meus cavalos O que você se agradá.

Amigo não quero, não, Estou obrigado e de mais, Que assim mesmo o meu tão magro, Faz mais que os seus não faz.

(O boi vê o vaqueiro chegar e o reconhece)

Ali vem um desgraçado, Sozinho, sem companheiro, Pelo andar do cavalo
Parece ser bom vaqueiro.

Pelo trajo que ele traz

$E$ a roseta da espora.

Não é vaqueiro daqui,

Me parece ser de fora.

(O vaqueiro captura o boi ferindo-lhe a perna)

Não me mate meu vaqueiro,

Não me mate aperriado,

Deixa contar minha vida

Que nunca tenho contado.

- Ainda que eu quisesse não posso Meu boi te fazer os gostos,

Pela viagem que fiz

Só lhe desejo ver morto.

(o vaqueiro mata o boi e o fazendeiro lhe diz)

Escolha das minhas filhas

A que vos se agradar;

Dou-lhe dez contos de réis

Quinze fazendas de criar.

ANEXo III

Variantes de romances analisadas para este trabalho

- $A B C$ do Boi Prata

cearense de Sílvio Romero (1954)

- Boi Adão piauiense de Rodrigues de Carvalho (1967)

- Boi Espácio

alagoana de Théo Brandão (1953)

cearense de S. Romero (1954)

pernambucana de Francisco Augusto Pereira da Costa (1908)

sergipana de S. Romero (1954)

- Boi Liso

pernambucana de F. A. Pereira da Costa (1908)

- Boi Mão de Pau rio-grandense do norte de Luís da Câmara Cascudo (1969)

- Boi Moleque cearense de Gustavo Barroso (1949)
- Boi Pintadinbo

cearense de R. de Carvalho (1967)

- Boi Surubim cearense de S. Romero (1954) Solfa registrada por L. da Câmara Cascudo (1969)

- Boi Victor cearense de R. de Carvalho (1967)

- Moda do Boi paulista de Amadeu Amaral (1948)

- Heroísmo de Valdevino na péga de um barbatão

Cordel de Manoel A. Campina (s.d.)

- Rabicho da Geralda cearense de José de Alencar (1960) cearense de R. de Carvalho (1967)

- Vaca do Burel pernambucana de S. Romero (1954) 


\section{BIBLIOGRAFÍA CITADA}

AlenCAR, José DE. 1959. "O Sertanejo", en José de Alencar - Obra Completa 3. Rio de Janeiro: Ed. José Aguilar Ltda.

-. 1960. "O nosso cancioneiro", en José de Alencar - Obra Completa 4. Rio de Janeiro: Ed. José Aguilar Ltda.

Amaral, Amadeu. 1948. Tradições populares. São Paulo: Instituto Progresso Editorial S.A. AugÉ, Marc. 1995 . Der Geist des Heidentums. Frankfurt am Main: Boer.

Barroso, Gustavo. 1949. Ao som da viola. Rio de Janeiro: Imprensa Nacional.

BASTOS, wILSON DE LIMA. 1979. Presença do boi no folclore brasileiro. Juiz de Fora: Centro de Estudos Sociológicos de Juiz de Fora.

Benício, Manoel. 1997. O rei dos jagunços. Rio de Janeiro: Jornal do Comércio e Fundação Getúlio Vargas.

Bogardus, EMORY S. 1987. "Status e personalidade", en Nanci Valadares de Carvalho (org.), Leituras Sociológicas: 134-135. São Paulo: Vertice e Revista dos Tribunais.

BRANDÃo, ThÉo. 1953. "Romance do ciclo do gado em Alagoas", Anais do $1^{\circ}$ Congresso Brasileiro de Folclore: 113-149. Rio de Janeiro: Ministério das Relações Exteriores.

CALAVIA SÁEZ, ÓSCAR. 1997. "Naturaleza, religión y cultura tradicional: Un ensayo sobre el pensamiento rústico". RDTP 52: 133-176.

Caro Baroja, Julio. 1964. "Honor y vergüenza". RDTP 20: 410-460.

-. 1984. "Toros y hombres sin toreros". Revista de Occidente 36: 7-26.

CARVAlHO, RODRIGUeS DE. 1967. Cancioneiro do Norte. Rio de Janeiro: INL.

CASCUDO, Lú́s DA CÁmARA. 1968. Vaqueiros e cantadores. Porto Alegre: Edições de Ouro.

- 1969. A vaquejada nordestina e sua origem. Recife: Instituto Joaquim Nabuco de Pesquisas Sociais e MEC.

- 1972. Dicionário do folclore brasileiro. Brasília: INL.

COOLEY, CHARLES HORTON. 1987. "Grupos primários e consciência coletiva”, en Nanci Valadares de Carvalho (org.), Leituras Sociológicas: 81-82. São Paulo: Vertice e Revista dos Tribunais.

CUNHA, EuClYDES DA. 1933. Os Sertões. Rio de Janeiro: Livraria Francisco Alves.

DA MATA, RoBerto. 1987. A casa \& a rua. Rio de Janeiro: Editora Guanabara.

-. 1990. Carnavais, malandros e heróis. Rio de Janeiro: Editora Guanabara.

- 1993. Conta de Mentiroso. Rio de Janeiro: Rocco.

DURANT, GILBERT. 1993. De la mitocrítica al mitoanálisis. Barcelona: Anthropos.

DURKHEIM, ÉmILE. 1987. "A solidariedade orgânica", en Nanci Valadares de Carvalho (org.), Leituras Sociológicas: 82-84. São Paulo: Vertice e Revista dos Tribunais.

—. 1989. As formas elementares da vida religiosa. São Paulo: Edições Paulinas. FIGUEIREDO, ALINE. 1994. A propósito do boi. Cuiabá: Editora UFMT.

Franco, Maria Sylvia DE CaRvalHo. 1976. Homens livres na ordem escravocrata. São Paulo: Ática.

FREITAS, ENELITA DE SOUSA. 2000. Rituais do boi no imaginário brasileiro. Belo Horizonte: Dissertação de mestrado em Literatura, Universidade Católica de Minas Gerais.

GaralgazA, Luis. 1990. La Interpretación de los simbolos. Barcelona: Anthropos.

García DE Diego, PILAR. 1953. "El testamento en la tradición". RDTP 9: 601-666.

LEACH, EDMUND. 1978. Cultura e comunicação. Rio de Janeiro: Zahar.

MAFFESOli, Michel. 1996. No fundo das aparências. Petrópolis: Vozes.

MENEZES, DJACIR. 1995. O outro Nordeste. Fortaleza: UFC.

MORIN, EDGAR. 1997. O homem e a morte. Rio de Janeiro: Imago. 
Pereira Da Costa, Francisco Augusto. 1908. "Folk-lore Pernambucano". Revista do Instituto Histórico Geográfico Brasileiro 70: 7-649.

PÉreZ VidAL, JosÉ. 1947. "Testamentos de bestias". RDTP 3: 524-550.

PitT-Rivers, Julian. 1984. "El Sacrificio del toro". Revista de Occidente 36: 27-47.

REDFIELD, ROBERT. 1941. The Folk Culture of Yucatan. Chicago: University Press of Chicago.

Romero, Sílvio. 1954. Cantos populares do Brasil. Rio de Janeiro: José Olympio. RoSA, JoÃo Guimarães. 1983. Sagarana. Rio de Janeiro: José Olympio.

SCHÜTZ, AlfRED und THOMAS LuCKMANN. 1979. Strukturen der Lebenswelt. Frankfurt am Main: Suhrkamp Taschenbuch Verlag.

SILVEIRA, Nise (org.). 1989. A farra do boi: do sacrifício do touro na antigüidade à farra do boi catarinense. Rio de Janeiro: Numen Editora e Espaço Cultural.

Slater, CANDACE. 1984. A vida no barbante. Rio de Janeiro: Civilização Brasileira. SuASsuna, ARIANo. 1974. Seleta em prosa e verso. Rio de Janeiro: José Olympio.

TALOŞ, ION. 1988. "Der Sieg über den Löwen“. Fabula 29: 96-138.

TÖNNIES, FERDINAND. 1926. Gemeinschaft und Gesellschaft, Grundbegriffe der reinen Soziologie. Berlim: Karl Curtius.

Vel.ASCO, HonORIO M. 1980. "Textos sociocéntricos. Los mensajes de identificación y diferenciación entre comunidades rurales". RDTP 35: 85-106.

Vianna, Oliveira. s/d. Evolução do povo brasileiro. São Paulo: Cia Editora Nacional. Viveiros De CASTRO, EDuARDo. 1986. Araweté, os deuses canibais. Rio de Janeiro: Zahar e ANPOCS. 